Notre Dame Law School

NDLScholarship

Natural Law Forum

$1-1-1967$

\title{
Abortion and the Catholic Church: A Summary History
}

John T. Noonan Jr.

Follow this and additional works at: http://scholarship.law.nd.edu/nd_naturallaw_forum Part of the Law Commons

\section{Recommended Citation}

Noonan, John T. Jr., "Abortion and the Catholic Church: A Summary History" (1967). Natural Law Forum. Paper 126. http://scholarship.law.nd.edu/nd_naturallaw_forum/126

This Article is brought to you for free and open access by NDLScholarship. It has been accepted for inclusion in Natural Law Forum by an authorized administrator of NDLScholarship. For more information, please contact lawdr@nd.edu. 


\section{ABORTION AND THE CATHOLIC GHURGH:}

\section{A SUMMARY HISTORY*}

John T. Noonan, Jr.

WHat determines when a being is human? When is it lawful to kill? These questions are linked in any consideration of the morality of abortion. They are questions central to any morality for man.

The teaching of any religious body is not, as such, natural law, if natural law be taken as the effort of rational man to perceive or express or create the norms of action best befitting his humanity. The teaching of a religious body may invoke revelation, claim authority, employ symbolism, which make the moral doctrine it teaches binding for believers in the religion but of academic concern to those outside its boundaries. The moral teaching of a religious body may also embody insights, protect perceptions, exemplify values, which concern humanity.

The teaching of the moralists of the Catholic Church on abortion is particularly rich in interaction between specifically supernatural themes e.g., the Nativity of the Lord and the Immaculate Conception of Mary and principles of a general ethical applicability. In its full extent, the teaching depends on the self-sacrificing example of the Lord - to the Greeks, foolishness. In its basic assumption of the equality of human lives, it depends on a Stoic, democratic contention which any man might embrace and Western humanism has hitherto embraced. In its reliance on ecclesiastical authority to draw a line, it withdraws from the sphere of debate with all men of good will; in its casuistic examination of principle, it offers instances where the common tools of moral analysis may be observed industriously employed. The teaching in its totality cannot be detached from the religious tradition which has borne it. The teaching in its fundamental questions about the meaning of love and humanity cannot be disregarded by those who would meet the needs of man humanly.

\section{The Context}

IN THE Mediterranean world in which Christianity appeared, abortion was

- To be published by the Harvard University Press in a volume of essays on abortion edited by André Hellegers, John T. Noonan, Jr., and Herbert Richardson. Copyright 1968 President and Fellows of Harvard College. 
a familiar art. The most learned of Greco-Roman gynecologists, Soranos of Ephesus (c. 98-138 A.D.), discussed abortion in terms of two main genres of abortifacients, phthorion, "which destroys what has been conceived," and ekbolion, "which expels what has been conceived." He then listed the following ways of achieving the destruction of the embryo: purging the abdomen with clysters; walking about vigorously; carrying things beyond one's strength; bathing in sweet water which is not too hot; bathing in decoctions of linseed, mallow, and wormwood; applying poultices of the same decoctions; injecting warm and sweet olive oil; being bled and then shaken after softening by suppositories. ${ }^{1} \mathrm{He}$ is opposed to the use of sharp instruments which may injure the mother. In addition he lists a number of contraceptives (atokia) which will also operate as abortifacients, in particular drugs composed of plant mixtures. These drugs will apparently operate at an early stage of the pregnancy if they have failed to prevent contraception; the abortifacients proper are intended for later stages of fetal life. As to the effectiveness of the means proposed, Soranos notes that contraception is surer and therefore to be preferred, but it would seem that some if not all of the abortifacient methods he proposes would have achieved the desired effect.

The reasons for abortion were as various as the means. Soranos notes three: to conceal the consequences of adultery; to maintain feminine beauty; to avoid danger to the mother when her uterus is too small to accommodate the full embryo. Plato and Aristotle thought of abortion as a way of preventing excess population. ${ }^{2}$ St. Ambrose was familiar with propertied families who practiced it in order not to divide their patrimony among too many children. ${ }^{3}$

The morality of practicing abortion was debated by physicians, philosophers, and religious teachers. The Hippocratic Oath was well known with its pledge "not to give a deadly drug [pharmakon] to anyone if asked for it, nor to suggest it. Similarly, I will not give to a woman an abortifacient pessary. In purity and holiness I will guard my life and my art."4 Influenced

1 Soranos, Gynecology, ed. J. Ilberg, in 4 Corpus medicorum graecorum 1.19 .60 (London and Berlin, 1927). I follow the translation of technical terms made by L. Edelstein and O. Temkin in their English translation of the Gynecology (Baltimore, 1956).

2 Plato, The Republic 5.461c; Aristotle, Politics 7.16, $1335^{\mathrm{b}}$.

3 St. Ambrose, Hexameron 5.18.58, Corpus scriptorum ecclesiasticorum LATINORUM (hereafter CSEL) 32.11.184.

4 Ludwig Edelstein, The Hippocratic Oath: Text, Translation, and InterpreTATION 3 (Baltimore, 1943). The commentators have generally taken the first part of the oath as a pledge not to give a poison or, as in Edelstein, not to participate in euthanasia, op. cit., p. 10. It seems to me that one reading of the oath is to see the "deadly drug" as one type of abortifacient which is rejected along with the pessary. This reading would accord with the paraphrase furnished by Soranos, who, at 1.19 .60 , says it forbids the furnishing of "an abortifacient" (phthorion). 
by the authority attributed to the oath as the work of Hippocrates, some physicians of the first century A.D. refused to prescribe abortifacients for anyone. They also had in mind that "it is the task of medicine to maintain and save what nature has engendered."5 Others, like Soranos himself, prescribed abortion only where completion of the pregnancy would endanger the mother. Another writing also ascribed to Hippocrates was cited where he himself told a girl how to accomplish an abortion by jumping. ${ }^{6}$ In the ideal commonwealth sketched by Socrates in Plato's Republic abortion is proposed as a solution to prevent endangering the optimum population of the state; it is impossible to say with what seriousness Plato endorses this suggestion.? Aristotle also proposes abortion if a couple has too many children for the good of the state, but he does so with remarkable caution, saying it is to be done before there is "sensation and life," and "what is right depends on the question of sensation and life," a restriction which in his biology might have permitted only contraception. 8

The Old Testament has nothing to say on abortion, but the Hellenic Jews of the diaspora developed an opinion. The Septuagint translation of Exodus 21.22 provided an opportunity. Where the Hebrew had said that where a man accidentally causes an abortion "life is given for life" only if the mother dies; the Greek read "life is given for life" if the embryo is "formed," so that an express penalty was provided for the abortion. In his first-century commentary Philo noted that by implication intentional as well as accidental abortion was thereby condemned. Philo himself associated abor-

5 Soranos, at 1.19 .60 .

- Hippocrates, The Nature of the Child, in Oeunges, ed. Littre, 7:409. Although this work may not belong to the Hippocratic corpus, it was accepted by Soranos as written by Hippocrates.

7 Plato, The Republic 5.461c. Sometimes Plato is cited as favoring abortion; but the reference in $T_{H z}$ LAws, $5,740^{d}$, is entirely a vague and general one to methods of restraining excessive fertility in an ideal city, and colonization is suggested as the last resort for population excess.

8 Aristotle, Politics 7.16, 1335b. As Aristotle himself leaves it a question, one can only suggest what the elements of the solution would have been for him. When an abortion occurs, distinct parts are found in an embryo if it is male and forty days old, or after ninety days if it is female (History of Animals $7.3 .583^{\mathrm{b}}$ ). This belief as to the time of formation of the fetus would suggest that there is no sensation before the fortieth day. Moreover, referring to growth in the early stages of the gestation of an animal, Aristotle speaks of its "nutritive soul," a soul which would be like that of a plant (THE Generation of Animals 2.5.714 $\mathrm{a}$ ) ; and the original state of animals is not sleep, but something resembling sleep, a state which plants are in (5.1). On the other hand, this nutritive soul has the capacity for using heat and cold as its "instruments" (ibid.). Where male and female are sentient, what the male contributes to generation is a "sentient soul" $(2.5 .741 \mathrm{~b})$. The animal "first and foremost lives because it can feel" (THE Soul 2.2.431'b). Can it be said that what is generated by the copulation of two animals is a plant? All that can be said with certainty is that Aristotle distinguished the first seven days from the later period of life, and considered that if an "effusion" of seed occurred then, that it was not the same as abortion of an embryo (History of ANimals 7.3.583a-b). 
tion with infanticide and the abandonment of children, practices of inhumanity which he now found regarded "with complacence" by many nations. ${ }^{9}$

Abortion, indeed, according to contemporary observers, was practiced very generally in the Greco-Roman world. The divided opinions of a few sages scarcely checked the powerful personal motives which made it attractive. The law of the empire punished abortion committed without the father's consent. ${ }^{10}$ It also punished the giving of drugs for abortion, ${ }^{11}$ but it is unlikely that the law was enforced unless the recipient died. The object of the law was not to protect the embryo as a human person, for it was regarded as part of the mother. ${ }^{12}$ The purpose was to restrain "bad example," i.e., the bad example of giving magical potions which could cause death to the recipient. ${ }^{13}$ As pagan observations and Christian complaints indicated, parents' freedom to dispose of their young offspring was taken for granted by the empire. ${ }^{14}$ That the Jews should have children born after their fathers' wills had been made, when heirs were no longer desired by the parents, was a cause for wonder to Tacitus. ${ }^{15}$ The Roman upper classes diminished during the empire; the decline was probably due, in good part, to the practice of contraception and abortion. ${ }^{16}$

It was in this culture generally distinguished by its indifference to fetal and early life that the Christian teaching developed; it was in opposition and conflict with the values reflected in popular behavior that the Christian word was enunciated. Where some wise men had raised voices in defense of early life so that the question was in the air and yet not authoritatively decided, where even the wisest presented hesitant and divided counsel, where other

O Philo, The Special Laws 3.20.110.

10 Digest, ed. Theodore Mommsen, 1 Corpus Juris civilis (Berlin, 1893) 47.11.4. According to Plutarch, Romulus in his original laws for Rome permitted a husband to divorce his wife for "pharmakeia" toward the children. Plutarch, Romulus 22. Probably the use of contraceptive or abortifacient drugs to prevent children is meant.

11 Digest 48.19.38.5; cf. Digest 48.8.8.

12 Id. at 24.4.1.1; 35.2.9.1.

13 The "bad example" rationale for the law is given by the jurist Paul, Digest 48.19.38.5, without explanation. As it also applies to the giving of aphrodisiac potions, I take it that the bad example relates to the character of the potion, not to the effect on the birth rate.

14 On the acceptance of abandonment of children by their parents, see Suetonius, Gaius Caligula 5; on the acceptance of infanticide, see Senrca, De IRA 1.15; cf. his praise of his own mother for not having had an abortion, unlike so many, Ad Helviam 16.1. For references where abortion is taken for granted by contemporary pagans, see Plautus, Trugulentus 1.2.99; Ovid, De amoribus 1.2.13; Juvenal, Satira 2.6; Aulus Gellius, Noctes atricae 12.1. For Christian criticisms of the prevalence of abortion see the texts cited at notes infra, 19-33. On the frequency of abortion see also J. H. Waszink, "Abtreibung," in Realexicon für Antike und Christentum 57, ed. Theodor Klauser (Stuttgart, 1950).

15 TAGITUS, Historiae 5.5.

16 John T. Noonan, Jr., Contrageption: A History op Its Treatment by the Catholic Theologians and Canonists 18-29 (Cambridge, 1965). 
authorities defended abortion, the Christians purposed a rule which was certain, comprehensive, and absolute.

\section{The Absolute Valuation, 50 A.D. -450 A.D.}

The New Testament and the Early Community. - The specific Christian teaching on abortion developed in a theological context in which the commands of the Old Testament to love God with all your heart (Deuteronomy 6.5) and to love your neighbor as yourself (Leviticus 19.18) were singled out as the two great commandments on which depended "the whole law and the prophets" (Matthew 22.40). The standard for fulfillment of these commandments was set in terms of the sacrifice of one man's life for another (John 15.13) and embodied in the self-sacrifice of Jesus. Jesus told the disciples, "This is my commandment, that you love one another as I have loved you" (John 15.32). In terms of his example; the commandment was "a new commandment" (John 13.34). The Christian valuation of life was made in view of this commandment of love.

The place of children in the Christian community was broadly established in the words of the Lord, "Suffer little children [paidia] and do not prevent them from coming to me" (Matthew 19.14; Mark 10.14; Luke 18.16). In Luke 18.15 , the children the Lord welcomed were expressly described as "newborn babies" (brephe). The ethos of the infancy narratives reflected a high interest in infant and fetal life. The infanticide practiced by Herod and its violent threat to the life of Jesus formed the introduction to the life of the Messiah (Matthew 2.1-18). Mary was described as having in her womb what was "from the Holy Spirit" (Matthew 1.18). In Luke she was greeted in pregnancy by Elizabeth "as the mother of my Lord," and the "fruit" of her womb was then described as "blessed" (Luke 1.42). The infant (brephos) in Elizabeth's womb "leaps". when Elizabeth is greeted by Mary (Luke 1.40). The interest in the behavior of this holy but not miraculous child of Elizabeth and the interest in the life in Mary's womb reflected the valuations of a community sensitive to the living character of the embryo, and the Gospel accounts must in turn have enhanced that sensitivity. What was unspoken was in its way as important as what was said in reflecting community valuations, attitudes, expectations. It was not necessary in this community to say that a man who protected the state by killing infants was not a good man. It was necessary to say that the first reaction of Joseph to Mary's unexplained pregnancy was "to put her away" (Matthew 2.19); it was not necessary to say that his first thought was not to procure an abortion.

At the level of specific moral rule, the Apostle Paul denounced the foolish 
carnality of the Christian community in Galatia (3.1-6), reminded them that there.was a law which was fulfilled in one word, "Love your neighbor as yourself" (5.14), and set out specific types of behavior which violated this law of love (5.19-21). The works of the flesh included not only "lecheries" and "wraths" but pharmakeia (5.20). Pharmakeia is a term best translated as "medicine" in the sense in which a North American Indian medicine man makes medicine. ${ }^{17}$ It is the employment of drugs with occult properties for a variety of purposes, including, in particular, contraception or abortion. ${ }^{18}$ Paul's usage here cannot be restricted to abortion, but the term he chose is comprehensive enough to include the use of abortifacient drugs. The association of these drugs with sins of lechery and wrath was indeed a constant aspect of the Christian approach to pharmakeia (the practice of "medicine") and pharmaka (the drugs employed).

The same association and same comprehensive use of the term appeared in the Apocalypse. The sinners who were not saved "did not repent of their homicides nor their medicine [pharmaka] nor their fornications nor their thefts" (9.21). The pharmakai, the medicine men, were condemned by the Lord with the homicides and the fornicators (21.8). Those outside the heavenly city were "the dogs and the medicine-men and the fornicators and the homicides and the idolaters and everyone who loves and practices falsehood" (22.15).18a

That abortion could have been specifically in the mind of the authors of Galatians and the Apocalypse, and that it was specifically dealt with by the early Christian communities, is established by several contemporary writings. The most important is the Didache, or Teaching of the Twelve Apostles. This ancient and authoritative statement of Christian principles in Syria was composed no later than 100 A.D. and may well have been written much earlier. ${ }^{19}$ Here a list of precepts. was given for the instruction of the Christian:

You shall not kill. You shall not commit adultery. You shall not corrupt boys. You shall not fornicate. You shall not steal. You shall not

17 See Clyde Pharr, The Interdiction of Magic in Roman Law, 63 Transactions AND Procereings of the American Philological Association 272-73 (1932). The word is regularly mistranslated as "sorcery" or "witchcraft" in English Bibles.

18 Plutarch, Romulus 22, in Parallel Lives.

18a "Dogs" may mean simply "heathen," but it was also applied to the sodomitic priests who served Astarte. See R. H. Charles, 2 A Critrcal Commentary and Exegesis of Revelations 178 (1920).

19 The later date is preferred by Theodore Camelot, "Didache," 3 Lexikon pür ThEoLOGIE UND KIRCHE 369 (1959). An early date, connecting the work with an apostolic mission at Antioch, is preferred by the author of a recent detailed study, JeAn-PAuL Audet, LA Didachì: Instructions des Apotres 197 (Paris, 1958). 
make magic. You shall not practice medicine (pharmakeia). You shall not slay the child by abortions (phthora). You shall not kill what is generated. You shall not desire your neighbor's wife. Didache 2.2.

In this list of related sins, one sentence expressly prohibited abortifacients. The commands on either side of this sentence dealt with other aspects of the same sin, as the commandments on sexual sins complemented each other. Abortion was ranked as a principal sin included with those sins expressly named by the Ten Commandments.

In the kernel of the Didache, which is probably its oldest part, the Two Ways, the Way of Life was contrasted with the Way of Death. The latter way was followed by sinners who included those who practice "medicine" and those who are "killers of the child, who abort the mold [plasma] of God." Again there was a complementary character to the acts denounced: pharmakeia, killing of the child, and abortion. The offense of abortion was seen as an offense against God because it attacked what $\mathrm{He}$ had made. It was associated with the sinful use of drugs to prevent birth and with the slaying of the child. It may be that both abortion of the mold and killing of the child were mentioned so that any distinction between formed and unformed fetuses would not provide an escape.

The somewhat later Epistle of Barnabas was based on the Didache and provided a commentary by its paraphrases and additions. It put the commandment on abortion in the Didache 2.2 in this framework:

You shall love your neighbor more than your own life. You shall not slay the child by abortions. You shall not kill what is generated. Barnabas 19.5.

The proscription was this related to the love of neighbor. The killing of the fetus to save one's own life was implicitly rejected.

A third writing is of special relevance to the apocalyptic style. This is the Apocalypse of Peter, a species of apocalyptic literature which "ranked next in popularity and probably in date to the canonical Apocalypse of St. John."20 Here there was a pit of torment for sinners, among them women "who have caused their children to be born untimely and have corrupted the work of God who created them." The phrasing was close to the "abort the mold of God" of the Way of Death in the Didache. Some of these women had conceived the children in fornication; others had husbands who were punished with them

zo Montague Rhodes James, The Apocryphal New Testament 505 (Oxford, rev. ed. 1953). 
because "they forsook the commandments of God and slew their children."21 The offense described was killing what God had made, an offense heightened because it was mothers who had killed their own offspring.

The Fathers.-Later in the second century the writing of the "most learned" of the Fathers, Clement of Alexandria, also contained a statement on abortion. In the Pedagogus Clement, the founder of the first school of Christian theology, sought to present Christ as the supreme educator for Christians and to provide teaching on Christian morality to the turbulent Christian community at Alexandria. He declared that Christians do not, in order to hide their fornication, "take away human nature, which is generated from the providence of God, by hastening abortions and applying abortifacient drugs [phthoriois pharmakois] to destroy utterly the embryo and, with it, the love of man."22 Here there is the same nexus of ideas found in the first century. Drugs to destroy offspring are associated with lechery. Their use is condemned not merely becaûse they furnish an aid to sexual sin or incorporate magic, but because they offend God in destroying what He has shaped and destroy the love of neighbor in destroying the fetus.

The foregoing documents were all addressed to Christian communities containing converts and impressing the new Christian morality upon them. Other evidence of Christian belief is furnished by the Christian claims addressed to the pagans. The contention was made that Christians are "homicides or devourers of men." The second-century philosopher and Christian convert Athenagoras answered this charge in his apologia for Christianity to the emperor:

How can we kill a man when we are those who say that all who use abortifacients are homicides and will account to God for their abortions as for the killing of men. For the fetus in the womb is not an animal, and it is God's providence that he exist. ${ }^{23}$

The dedicated Christian defense of life at the embryonic stage seemed to Athenagoras the surest proof of the Christian reverence for life.

In a similar vein the lawyer Minucius Felix repelled the charge of infanticide in his apologia (c. 190-200): Who would believe that the tender

21 Id. at 510 (James' translation from the Ethiopic text). In the same style the much later Apocalypse of Paul condemns women who "defiled the creation of God when they brought forth children from the womb," i.e., by abortion (id. at 545).

22 Clement, Pedagogus 2.10.96.1, Die grieschen christlichen Schriftsteller der ERSTEN DREI JAFRH UNDERT (hereafter GCS).

29 Athenagoras, Embassy for the Christians, Patrologia graeca 6.919 (hereafter $P G)$. 
bodies of infants would be destroyed? "No one would believe it unless he dared it." In charging this crime the pagans reveal their own conduct. They expose their unwanted children to wild beasts and birds or strangle them. "By drinks of drugs they extinguish in their viscera the beginning of a manto-be and, before they bear, commit parricide." These things are derived from their gods, for Saturn devoured his own children. ${ }^{24}$ The use of the term parricidium is especially striking here. Roman law had no generic term for the "killing of a man," and so Minucius used the closest legal term in use, "parricide," the killing of a near relation, designating a crime punished with great severity by the law. It conveyed the idea of heinous killing at the same time that Minucius expanded its meaning far beyond its recognized legal meaning to encompass abortion. ${ }^{25}$ In describing the pagans' practice, he expressed his own judgment that it was wrong. At the same time he made the suggestion, of much psychological interest, that the Greek myth of a god devouring his children was related to abortion.

In a parallel passage Tertullian in his apologia to the pagans dismissed the charge of infanticide practiced by Christians and asserted:

For us, indeed, as homicide is forbidden, it is not lawful to destroy what is conceived in the womb while the blood is still being formed into a man. To prevent being born is to accelerate homicide, nor does it make a difference whether you snatch away a soul which is born or destroy one being born. He who is man-to-be is man, as all fruit is now in the seed. ${ }^{26}$

The substance is the same as the Two Ways: the mold in the womb may not be destroyed. The offense is expressed as the killing of a potential human, an act which seems forbidden by the commandment, "You shall not kill."

In addition to its expression in formal moral teaching and apologias to the gentiles, the Christian belief was expressed in the course of controversy within the Church. Abortion was a serious charge in ecclesiastical disputes. When the ex-slave Calixtus, bishop of Rome, permitted Christian women to marry

24 Minucius Felix, Octavius, CSEL 2.43.

25 On the meaning of parricidium see T. Mommsen, Römisches STrafrecht 613 (1899).

26 Tertullian, Apologeticum ad nationes 1.15. The relation of Tertullian to Minucius is discussed in Marti Sordi, L'apologia del martire romano Apollonio come fonte dell Apologeticum di Tertulliano e $i$ rapporti fra Tertulliano e Minucio, 18 Ruvsta do storIA DELLA Chiesa in Italia 169-188 (1964). Another example of apologetical criticism of pagan inhumanity toward children is provided by Lactantius, Divinarum institutionum 6 . His strong terms seem principally aimed at infanticide and the abandonment of children to beasts, but may include abortion and reflect the teaching of the Didache when he says that "with wicked hands they corrupt the works of God." The central thought is, "It is always wrong to kill a man; this animal God willed to be sacred," PArrolooin ratina 6.707-708 (hereafter $P L$ ). 
their slaves though the marriages were unrecognized by Roman law, some women did not want to draw attention to their union, and used drugs to produce sterility or "bound themselves tightly to expel a fetus already engendered." According to Calixtus' critic and bitter rival, Hippolytus, this conduct was homicide, and Calixtus was responsible for encouraging it.27 When Novatian broke from Rome because its bishop accepted the repentance of apostates, his foe Cyprian wrote of him that he was himself guilty of serious sin: he had struck his pregnant wife to cause an abortion. He has "committed parricide"; "he has killed a son who was being born."28 A lawyer like Minucius, Cyprian used the legal term, parricide. The charge of a crime inexpiable in life was no doubt especially effective against a man who denied others an opportunity to repent.

As the Church emerged as a legal religion and a social force in the fourth century, the sentiments on abortion so uniformly expressed in the first two centuries of Christian life took the form of legislation. There already existed a rule excluding from the Church for life women who conceived in fornication and committed an abortion. The Council of Ancyra in 314, a gathering of a dozen Eastern bishops representing Syria and Asia Minor, denounced such women, who "slay what is generated and work to destroy it with abortifacients"; but "more humanely" the Council reduced their penance to ten years. ${ }^{29}$ The Council retained the life penance for voluntary homicide, so that the reduction marked a recognition of mitigating circumstances in the character of the crime, while its gravity was indicated by the still severe penalty imposed. In the West, in some contrast, the movement was toward greater sanctions. At Elvira on the Iberian peninsula, a council held in 305 excommunicated women committing abortion after adultery and declared that they were not to be readmitted even at the point of death.30

These laws, like the earlier condemnations, made no distinction between the formed and unformed fetus. In the course of the fourth century this distinction, based for Christians on the Septuagint translation of Exodus 21.22, became a focus for analysis. In the East the Apostolic Constitutions, an apocryphal set of apostolic canons from Syria, condemned the killing of a "formed fetus." 31 In the West, St. Jerome explained to a female correspondent, Algasia, that "seeds are gradually formed in the uterus, and it is not reputed homicide until the scattered elements receive their appearance and mem-

27 Hippolytus, Elenchos 9.12.25, GCS 26.250.

28 Cyprlan, Epistle 52, CSEL 32.619.

29 Council of Ancyra, canon 21, J. D. Mansi, SAcrorum conciliorum nova et A MipLIS SIMA COLlectio (hereafter Mansi) 2.5.19.

so Council of Elvira, canon 53, Mansi 2.16.

31 Didiscalia et Constitutiones Apostolorum 7.3.2, ed. Francis X. Funk (Paderborn, 1905). 
bers."32 Augustine, commenting on a Latin translation from the Septuagint, observed that at Exodus 21 the question of ensoulment was usually raised, and

because the great question about the soul is not to be hastily decided by unargued and rash judgment, the law does not provide that the act pertains to homicide, for there cannot yet be said to be a live soul in a body that lacks sensation when it is not formed in flesh and so not yet endowed with sense. ${ }^{33}$

This was a distinction accepted out of a cautious agnosticism on ensoulment; both Jerome and Augustine affirmed that, in fact, man did not know when the rational soul was given by God. ${ }^{34}$

As far as Jerome and Augustine were concerned, the theoretical distinction led to no difference in moral disapprobation. They simply adopted language broad enough to condemn both contraceptive acts and acts destroying the fetus after conception. Jerome wrote to his star pupil Eustochium on how to preserve her virginity among the temptations to adolescents in Rome. He denounced those Christian girls who, saying "all things are pure to the pure," had affairs and sought to prevent or conceal pregnancy. Some "will drink sterility and kill a man not yet born." Others will use potions to commit abortions. These are parricides, and as sometimes the abortifacients are fatal to them, too, they go to judgment thrice condemned as adulteresses, killers of their children, and killers of themselves. ${ }^{35} \mathrm{Here}$, in the language of Minucius, abortion became parricide, and the age of the fetus was unmentioned.

Augustine in his anti-Pelagian work, Marriage and Concupiscence, analyzed abortion with his usual attention to psychology. Using terms that seem to anticipate modern analyses of sadism, he described it as the work of minds characterized by "lustful cruelty" or "cruel lust." Speaking of the married who avoided offspring, he declared,

Sometimes [Aliquando] this lustful cruelty or cruel lust comes to this that they even procure poisons of sterility, and if these do not work, they extinguish and destroy the fetus in some way in the womb, preferring that their offspring die before it lives, or if it was already alive in the womb, to kill it before it was born. Assuredly if both husband and wife are like this, they are not married, and if they were like this from the beginning,

32 Jerome, Epistles 121.4, CSEL 56.16.

s3 Auoustine, On Exodus 21.80, CSEL 282.147. The old Latin text spoke of "aborting an immature one," A. E. Brooke and Norman Mclean, The Old Testament in Greer (1909).

94 Augustine, De origine animae 4.4 ( $P L$ 44.527); Jerome, On Ecclesiastes 2.5.

35 Jerome, Epistle 22, To Eustochium 13, CSEL 54.160-61. 
they come together not joined in matrimony but seduction. If both are not like this, I dare to say that either the wife is in a fashion the harlot of her husband, or he is an adulter with his own wife. ${ }^{36}$

Augustine thus condemned three kinds of act: contraception, the killing of the fetus before it is formed or "lives," and the killing of the live fetus. The analysis was a new approach in treating each of these acts as a sin against marriage. Elsewhere Augustine treated abortion as a form of homicide. ${ }^{37}$

The preservation of life within the womb also became a reason for restricting what St. Paul in the First Epistle to the Corinthians had set out in terms of justice, the right to intercourse within marriage (1 Corinthians 7.3-5). Led by Stoic thought to restrict intercourse to procreative purpose alone, many Christian writers prohibited the necessarily nonprocreative intercourse of the pregnant. But an additional reason for the prohibition was found in the danger to the embryo that such intercourse was believed to create. Commenting on the pregnancy of Elizabeth in the Gospel of Luke, Ambrose stated the belief that intercourse in pregnancy "contaminated" the offspring. ${ }^{38}$ Even more forcefully, Jerome incorporated a quotation from Seneca vigorously attacking intercourse from "affection," not "judgment," and urging restraint at least in pregnancy, so as not to "destroy the offspring." 39 Thus the risk of abortion became a reason for limiting what St. Paul had described as a duty.

The principal texts quoted from Jerome and Augustine were to be the loci classici on abortion in the West. In the East, St. John Chrysostom preached against abortion as encouraged by married men engaged in intercourse with prostitutes: "You do not let a harlot remain only a harlot but make her a murderess as well." 40 In the most definitive statement by a leader of the Greek Christian community, St. Basil of Cappadocia set out in a letter to Amphilocius the standards of the Church as he knew them in the late fourth century. The distinction founded on the Septuagint was rejected: "the hairsplitting difference between formed and unformed makes no difference to us." "Whoever deliberately commit abortion are subject to the penalty for

36 Augustine, De Nuptis et concupiscentia 1.15.17, CSEL 42.229-30.

37 See Constancio Palomo Gonzalez, El Aborto en San Augustin (Salamanca, 1959). In treating abortion as parricide, Augustine followed his old teacher St. Ambrose who had denounced the use of a "parricidal potion" of married mothers "to take away life before it is transmitted," Hexameron 5.18.58, CSEL 321.184. Ambrose, while speaking thus of parricide, had emphasized in particular the cruelty of mothers in destroying their children and invoked the "piety" of birds to their young to rebuke them.

38 Ambrose, Expositio Evanoelit secundum Lucam 1.43-45, CSEL 324.38-39.

39 Jerome, Contra Jovinianum 1.49 , in Seneca: Fragmenta n.84, ed. F. G. Haase (Leipzig, 1897). In its original context in Seneca, the injunction not to destroy the offspring could be taken as a warning against abortion of any kind.

40 John Chrysostom, Homily 24 on the Epistle to the Romans, $P G$ 60.626.27. 
homicide." 41 The penance, however, was that set by Ancyra, ten years. Unlike Ancyra, Basil did not restrict his condemnation to women who conceived in fornication. Like Jerome he noted that often the potions killed the mothers, too. Like the Didache, he made his condemnation repetitiously: In general, sodomists, homicides, medicine men (pharmakoi), adulterers, and idolaters were condemned together; ${ }^{42}$ specifically, those were classed as homicides who "gave abortifacient drugs" (amblothridia pharmaka) and those who "receive what entraps the embryo."43 Basil's comprehensive summing up on abortion in a document later characterized as "The Canonical Letter" was to constitute the fundamental norm on this behavior for the Greek Church.44

By 450 the teaching on abortion East and West had been set out for four centuries with clarity and substantial consistency. There was a distinction accepted by some as to the unformed embryo, some consequent variation in the analysis of the sin, and local differences in the penance necessary to expiate it. The sin itself was often associated with lechery, sometimes with marriage. The usual method of accomplishing it was by drugs, sometimes associated with magic, sometimes with danger to the user. The motive animating it was seen variously as shame, as avarice, as lust. Although therapeutic and social reasons for abortion were known from the best of doctors and philosophers, these reasons were never mentioned as justification. All the writers agreed that abortion was a violation of the love owed to one's neighbor. Some saw it as a special failure of maternal love. Many saw it also as a failure to have reverence for the work of God the creator. The culture had accepted abortion. The Christians, men of this Greco-Roman world and the Gospel, condemned it. Ancient authorities and contemporary moralists had approved, hesitated, made exceptions; the Christian rule was certain.

\section{Transmission, $450-1450$}

IN THE period from 450 to 1100 , when monks and bishops were the chief transmitters of Christian moral ideas, the teaching on abortion was reiterated. It was conveyed by enactments against abortion by local synods. ${ }^{45}$ It was conveyed by collections which contained the canons of Elvira or the canons of the more prestigious council of Ancyra. By the eighth century Ancyra was

41 Basil, Letters 188, PG 32.672.

42 Id. at 674 .

43 Id. at 678 .

44 On the authority of "The Canonical Letter," see J. Gribomont, Introduction to $P G$ 32 (rev. 1960).

45 See Roger John Huser, The Grime of Abortion in Canon law 33-39 (Washington, 1942). 
the law of the Frankish kingdom of Charlemagne. ${ }^{46}$ It was conveyed by collections which contained St. Jerome on homicide by abortifacients. ${ }^{47}$ The penitentials developed by the monks for use in hearing confession regularly prescribed specific penances for abortion, ranging from one to ten years for the killing of an embryo. ${ }^{48}$ When interrogatories for use in questioning penitents were devised in the tenth century, questions on abortion were included. ${ }^{49}$ The early Christian and patristic attitudes were faithfully preserved in the various channels communicating the teaching of past authority and instilling its observance.

Liturgy and Canons.-Interest in the conception of the Lord was fostered by popular reflection on the Gospel stories, and the liturgical embodiment of this reflection also played a part in the development of reverence for life in the womb. The December 25th feast of the Nativity of the Lord was established by the late fourth century. By the seventh century in the East a feast was established marking the Annunciation to Mary or "the Conception of Christ."50 This feast was established on March 25, with the implication that nine months had elapsed between conception and birth, and with the further implication that what had come from the Holy Spirit to Mary had been holy from the moment of conception. The feast of the Conception of Christ, it may be supposed, served, beyond its primary meaning, as a symbol of the sacredness of any conception. In the late sixth century there also came into existence in the East the feast of the Nativity of Mary, fixed on September 8.51 A century later the feast of Mary's conception by St. Anne was established on December 9 with an elaborate vigil on December 8.52 The prayers in the office of the day rejected the belief that Mary had been "born after seven months," 53 an apparent repudiation of the view that her soul was infused

46 Id. at 21 .

...47. E.g., in the eighth century, "Simulated Virgins and. Their Morals," in Womanly Questions, Die Irische Kanonsammuuno, ed. F. W. H. Wasserscheben (Leipzig, 1885).

18 See Noonan, op. cit. supra note 16, at 164. Some penitentials have lesser penalities for the destruction of what is less than an embryo-apparently a reflection of the old distinction between the formed and the unformed.

49 Burchard of Worms, "Interrogatory," Decretum 19.4, PL 140.972.

so-P. Toschi, "Annunziazione," 1 Enciclopedeia Catrolica 1384. It has been argued that March 25 was fixed first as both the date of conception and the death of Christ. The coincidence of this birth and death date on this day was asserted by AugustiNe, DE reInrtatz 4.5, PL 42.894. However, the better opinion appears to be that Christmas was set on December 25 because that was the winter solstice. See C. Smith, "Christmas and Its Cycle," 3 New Catholic Encychopgdia 656. On this view March 25 would have been set in view of the previously established date for the nativity.

o1 Prancis Dvornik, The Byzantine Church and the Immaculate Conception, in $T_{\mathrm{HE}}$ Dogma of the Immaculate Conception 90, ed. E. O. O'Connor (1958).

s2 Cornelius A. Bowman, The Immaculate Conception in the Liturgy, id. at 115.

63 Id. at 117 . 
after her conception. The feast in honor of Christ's conception could be explained as a feast for a conception of a divine man; but the conception of Mary was believed to be the conception of a human being by the intercourse of humans. The recognition that she deserved honor at conception had specific implication for the humanity of all men.

In the great formative period of Western canon law between 1140 and 1240 , and in the course of the contemporary conflict with the Cathars, who opposed all procreation, Augustine on abortion was incorporated in the basic collection of canons made by Gratian. There, in a section devoted to marriage, appeared the Augustinian denunciation of the lustful cruelty of the married who procured abortions. It was now the canon Aliquando. ${ }^{54}$ Until the new Code of Canon Law in 1917 this text was to instruct all students of the canon law. It was supplemented by Gratian's answer to a question he himself proposed, "Are those who procure an abortion homicides or not?" The answer was supplied by Jerome to Algasia and Augustine on Exodus, quoted earlier, plus a spurious quotation from Augustine which taught expressly that there was "no soul before the form."55 Clearly, in Gratian, abortion was homicide only when the fetus was formed.

The distinction was reaffirmed in slightly different language by Innocent III. A priest incurred "irregularity," i.e., he was suspended from his functions, if he committed homicide. The case was put of a Carthusian monk who in playing had accidentally caused his mistress to abort. Was he irregular? Innocent III held that he was, if the fetus was "vivified." The decretal entered the universal law of the Church in the decretal collection of Gregory IX as the canon Sicut $e x$ in the comprehensive section entitled, "Voluntary and Chance Homicide."56 "Vivified" was treated as the equivalent of "ensouled," and the decretal was seen as implying that homicide occurred only after ensoulment had taken place according to the texts furnished by Gratian. ${ }^{57}$

At the same time the decretals of Gregory IX provided a new canon, Si aliquis, derived from a tenth-century penitential of Regino of Prüm. Si aliquis declared:

If anyone for the sake of fulfilling lust or in meditated hatred does something to a man or a woman, or gives them to drink, so that he cannot generate, or she conceive, or offspring be born, let it be held as homicide. ${ }^{58}$

s4 Gratian, Decretum 2.32.2.7, in Corpus Juris canonici, ed. E. Friedberg (Leipzig 1879-1881).

$55 \mathrm{Id}$. at 2.32.2.8-10.

so Gregory IX, Drgrktales 5.12 .20 , in Corpus J Uris canonici.

57 Glossa ordinaria at 5.12.20.

58 Decretales 5.12.5. 
The canon thus applied the penalty for homicide to contraception and to abortion at any stage of fetal life. How was it reconcilable with Sicut ex? The usual answer was that $S i$ aliquis merely stated that the acts it condemned were to be punished "as homicide." It set the law for all persons. Sicut ex added the extra penalty of irregularity for clerics only in the case of true homicide.59 Thus the ordinary law of Si aliquis went beyond what was held to be speculatively true by declaring that, for practical purposes of penance, abortion of any fetus must be put on a par with the killing of a man.

The concern with the sanctions for abortion was not a mere academic exercise. A wide variety of techniques for abortion was provided to medieval physicians and students by the Canon of Medicine of Avicenna, translated from Arabic to Latin by Gerard of Cremona about 1150 and thereafter until the middle of the seventeenth century the standard text of European medical schools. ${ }^{60}$ Avicenna taught that abortion might sometimes be necessary where birth would endanger the life of the mother. For such cases he set out a list of measures. They included exercise, the carrying of heavy weights, the evacuation of the humors, the insertion by instrument in the matrix of drugs to kill the fetus, and the drinking of various drugs in potions. ${ }^{61}$ Baths, excessive exercise, and violent jumping were also observed to be causes of abortion. ${ }^{62}$ Abortion was said to be most likely at the beginning and near the approach of birth. ${ }^{63}$ A number of the means described were doubtless effective to accomplish their objective. The information about them was communicated by the wide distribution of the Canon of Medicine itself and by books deriving their information from it. St. Albert the Great, for example, in his encyclopedic work on plants described the abortifacient properties of several vegetables; writing on animals he tells how to accomplish an abortion. ${ }^{64}$ His principal source was Avicenna.

The analysis and treatment given by the canon law dominated both canonical and theological treatment of what was not an unknown sin. Many writers, influenced by Si aliquis, followed the suggestion of Hostiensis that the use of "poisons of sterility" was "interpretively homicide" in both contra-

50 The explanation of the compiler of the decretals, St. Raymond, in Summa CoNPESSARTORUM 2.1.4.

6o Charles Singer and E. Ashworth Underwood, A Short History of Medicine 76 (Oxford, 2nd ed. 1962).

61 Avicenna, De regimine abortus, Book 3, Fen 21, Tract 2, c. 12 of Canon Medicine, trans. Gerard of Gremona (Venice, 1608). The index of this edition lists drugs which "produce an abortion." The operation producing evacuation of the humors is phlebotomia, defined 1.4.20.

${ }_{62}$ Id. at c. 8, "De abortu."

$63 I d$. at c. 8.

B4 Albert, De vegetabilibus et plantis, in 10 OPERA OMNIA, ed. A. Borgnet (Paris 18901899), 6.1.16, "Colloquintida"; 6.1.26, "Myrrha"; 6.24, "Coriandrum"; 6.2.17 "Scamonea." De animalibus, 11 OPERA OMNIA 10.2.2. 
ception and early abortion. ${ }^{65}$ Among those classifying abortion as a form of homicide were the great lay canonist Joannes Andreae, the Franciscan summists Monaldus and Astesanus, the English canonist William of Pagula, and the German Dominican John Nider. ${ }^{66}$ In the same way Chaucer's Parson classified the destruction of the fetus among the sins of wrath. ${ }^{67}$

Theological Analysis.-For those who gave more weight to the express canonical texts on ensoulment a different approach to early abortion was necessary. In the standard text of the schools, the Sentences of Peter Lombard, the texts chosen by Gratian were repeated. As in Gratian's framework, Aliquando formed a central passage in the analysis of the purposes of marriage. ${ }^{68}$ The pseudoAugustinean citation on ensoulment in Gratian was confidently repeated to show that the soul was not inserted until the body was formed. ${ }^{69}$ Peter Lombard himself observed, "From this it appears that they are homicides who procure an abortion when the fetus is ensouled."70 The implication left by the Sentences from the use of Aliquando was that before ensoulment abortion was a sin against marriage. This judgment was explicitly made by St. Albert speaking of use of "the poisons of sterility," the generic term for both contraceptives and abortifacients. ${ }^{71}$ In his youthful commentary on the Sentences, St. Thomas Aquinas treated the use of these drugs as a sin "against nature because even the beasts look for offspring."72 He did not repeat this analysis again, and it was not in harmony with his later treatment of sins against nature as sins preventing insemination in intercourse. ${ }^{73} \mathrm{He}$ was clear that there was actual homicide when an ensouled embryo was killed. ${ }^{74}$ He was equally clear that ensoulment did not take place at conception. ${ }^{75}$ There was

65 Hostiensis, Summa aurea (Lyons, 1542) 5, "Homicidium" 1.

66 Joannes ANDreae, Novella commentaria in libros decretalium (Venice, 1581) 5.12; Monaldus, Summa perutilis (Lyons, 1516) f.135 r.; Astesanus, Summa de casibus conscientiae (Ratisbon, 1780) 8.9. William of Pagula, Summa summarum (Huntington Library, MS 1638), at "Homicidium voluntarium"; JOHN NIDER, De LEPRA MORALI (Paris, 1490) 2.7.2.

67 Geopprey Chauger, The Canterbury Tales (ed. F. N. Robinson, 1957), "The Parson's Tale," lines 570-80.

68 Peter Lombard, Libri IV Sententiarum (Quarrachi, 1916) 4.31.

69 Id. at $4.31 ; 2.18$.

70 Id. at 4.31 .

71 Albert, In libros IV Sententiarum 4.31.18.

72 Thomas, In libros IV Sententiarum 4.31.2.3, "Expositio textus."

73 Thomas, Summa theoloorca (Leonine ed.) 2.2.154.11 and 12.

74 Id. at 2.2.64.8, reply to objection 2. The topic was "whether one who kills a man by chance incurs the guilt of homicide?" Like the Septuagint version of Exodus, Thomas held that striking a pregnant woman was an illicit deed, and if the death of either the woman or an ensouled fetus followed, it was homicide.

75 That a being does not have a rational soul at conception formed a principal objection for him to the doctrine of the Immaculate Conception of Mary, which he denied, IN LIBRos SENTENTIARUM 3.1.1: she was "sanctified" in the womb, but "when it definitely was, is uncertain." 
sin, but not the sin of destroying a man in destroying the conceptus in its early stage, for "seed and what is not seed is determined by sensation and movement"; this phrase seems to mean that, at the early stage, seed is being destroyed, not man. ${ }^{76}$ The result was that there was a period of fetal existence where Thomas's later writing did not specify the offense involved in fetal destruction yet where, according to his clear opposition to contraception, he believed a sin was being committed. It was, however, according to both Albert and Thomas, mortal sin to have intercourse in pregnancy with the risk of abortion. Moreover, both accepted Avicenna's opinion that such risk was especially acute at the beginning. ${ }^{77}$ Hence, even for the early state of pregnancy, they held the life of the fetus more valuable than the obligation of the marital debt.

As for deliberate abortion, Thomas considered only one case where justification was alleged, but it was the case with the greatest appeal in a theologically-oriented society: the case of abortion for the child's own good, abortion to baptize the child. In medieval society this case had the appeal of abortion of a defective child in a modern society. In the medieval case it would have been to prevent the child from suffering eternal loss of happiness, as in the modern case it would be to prevent the child from suffering the loss of secular happiness. Why not "split the mother" and extract the fetus, so that, baptized, he "may be freed from eternal death"? To this appeal Thomas replied,

Evils are not to be done that good may come from them, Romans 3; and therefore a man ought rather to let the infant perish than that he himself perish, committing the criminal sin of homicide in the mother. ${ }^{78}$

The text cited from St. Paul was in itself not decisive; the reference was to a rejection by Paul of his opponents' charge that "we do evil that good may come" (Romans 3.8). What was decisive was the perception that God's providence could not be anticipated by a paternalism which would have permitted man to act as God in determining human life and assuring its salvation.

The case of abortion for the child's own good was rejected. What of abortion to save the mother? Thomas did not face the case expressly, but he posed broader principles of relevance; and, as the case itself was known as a medical problem from Avicenna, it cannot be supposed that he was

\footnotetext{
76 The passage occurs in explaining while Aristotle accepted a lesser evil in accepting abortion, IN OCTO LIBROS POLITICORUM 7.12.

77 Albert, In libros sententiarum 4.31.22; Thomas, In libros sententiarum 4.31.2.3, "Expositio textus."

78 ThOMAS, IN LIBROS SENTENTIARUM 1.1 .3 ad 4.
} 
unaware of the relation of the principles to therapeutic abortion. ${ }^{79}$ The question was put, "Is it lawful for someone to kill someone in defending himself?" The case posed was not, as many later interpreters would have it, a case of unjust aggression. When Thomas wanted to characterize the one being killed he used the terms "sinner" and "innocent." 80 Here the one killed was merely "someone." His answer to the question was, "If someone kills someone in defense of his own life, he will not be guilty of homicide." 81 The conclusion was based on the principle that "nothing prevents there being two effects of a single act." One effect could be "in intention," the other "beyond intention"; and by intention Thomas meant the mental state of the person killing, for the act itself had as finis operis the double end of preservation of life and the killing of another. The act was lawful, because "what was intended was the preservation of one's own life." This intention was not sinful, for it is "natural to everyone to preserve himself as far as he can." The "justification was necessity. Fornication, for example, was a lesser sin, but was always mortal, for "it is not ordered to the preservation of one's own life from necessity like the act from which homicide sometimes follows."82 Put another way, every lie is a sin, and homicide is a worse sin than lying; yet, unlike lying, homicide can sometimes be lawfully done "as when a judge kills a thief." Hence one can say, "Homicide imports not the killing of a man"; it imports "the undue killing of a man." You can then conclude, "Homicide is never lawful, although it is sometimes lawful to kill a man." 83

From these principles, that all killing is not forbidden, that one may lawfully act to preserve one's own life, and that an indifferent act may be justified by a good intention, an argument could be made to justify abortion to save the life of the mother. Much would depend on how absolutely Thomas meant his declaration in other contexts that "in no way is it lawful to kill the innocent." 84 If the statement held literally, it would seem to preclude capital punishment for a repentant thief, who has become innocent, as most men

79 A leading teacher at Paris in the late twelfth century, Peter Cantor, had condemned the opinion of some that a woman could "procure a poison of sterility" to prevent conception when childbirth would be fatal to her. Peter said simply, "This is prohibited in every case" (Peter Cantor, Summa de sacramentis 350, ed. Jean-A. Dugauquier, III² 463-64). He doubtless had in mind the controlling canons, Aliquando and Si aliquis.

80 Thomas, Summa theologica 2-2.64. 2. and 6.

81 Id. at 2-2.64.7.

82 Id. at ad 4.

83 Thomas, Quodlibeta 8.14.

84 Thомas, Summa тнeologica 2.2.64.6. The thrust of this article is the distinction between "sinners" who may be killed by public authority and the "innocent" who may not. In De malo he stated, "to kill the innocent imports a determination of evil, and this can never be well done" (De malo 13.4 ad 11). The remark occurred in a discussion of the intrinsic evil of usury, and it would probably be unwise to read as applying definitely to every case of killing from necessity. 
become innocent, by repentance; yet Thomas justified capital punishment. Applying the principle absolutely, he would have held sinful many acts in warfare such as the killing of enemy soldiers who were in good faith or the killing of infants in a fortress. It cannot be said definitively how Thomas would have answered in these cases or in the case of therapeutic abortion to save the mother's life.

In summary, the monks had transmitted the apostolic and patristic prohibition of abortion. The canon law set it out as a universal requirement of Christian behavior. The theologians explored the relation of the law to the theory of ensoulment, but on one basis or another condemned abortion at any point in the existence of the fetus. The prohibition was still absolute. But the basis for weighing the life of the embryo against other values had been laid, and in the next period of development a balance was to be sought.

\section{The Balance of the Casuists, 1450-1750}

Therapeutic Abortion.-The work of St. Antoninus of Florence may be taken to mark the beginning of a new era of thought on abortion, for he brought into the main line of moral theology an opinion of an obscure thirteenth-century theologian in favor of abortion to save the mother. His author is another Dominican from Thomas' country, John of Naples, in 1315 teacher at Paris, later holder of a chair of theology at Naples. ${ }^{85} \mathrm{John}$ based his position on the distinction between the ensouled and unensouled fetus in addressing himself to the duty of the physician. A doctor sinned in giving medicine to cause an abortion "to. preserve a pregnant woman" when the fetus was ensouled, for, when "one .cannot help one without hurting the other, it is more appropriate to help neither." But if the fetus was not ensouled, then the physician "ought to give such medicine," because "although he impedes the ensoulment of a future fetus, he will not be the cause of death of any man." 86

It cannot be said that Antoninus adopted this opinion as his own. He quoted it in his treatise on the sins of the different professions. and added the remark that, if there was a doubt as to the ensoulment, the physician sinned mortally "because he exposes himself to the risk of mortal sin, that is, to homicide." $87 \mathrm{He}$ had earlier spoken as though all abortion were homicide,

85 H. HURter, Nomenciator literarius thrologiae catholicae (Innsbruck, 1906) 2.537 .

86 John of Naples, Quodlmeta, as quoted in Silvester da Prizras, Summa sumMARUM QUAE SYLVESTRINA Dicitur (1518) at "Medicus," 4.

87 Antoninus, Summa sacrae theologiae (Venice, 1581) 3.7.2, "The Various Vices of Physicians." 
though only the killing of the formed embryo was so held by the law. ${ }^{88}$ In reciting the opinion of John of Naples he did not withdraw his earlier views, but must have considered that John of Naples' opinion was also probable.

Sixty years later a less important but influential Dominican, Sylvester da Prieras, followed Antoninus' example. He quoted John of Naples with the same caution as to where there was doubt of ensoulment. ${ }^{89}$ The leading Dominican moralists, Cajetan and Soto, made no comment of any kind. Then the opinion was formally embraced by Martin Azplicueta, "the doctor of Navarre," the guide in moral questions of three popes, and the leading canonist of the sixteenth century. 90 Where the physician "believed with probability" that the fetus was not ensouled, he was not the cause of death of another. ${ }^{91}$ Azplicueta was under Gregory XIII a principal consultor of the Sacred Penitentiary, the Roman tribunal for deciding cases of conscience submitted to confessors, and he noted elsewhere that the rule of the Penitentiary was to treat a fetus over forty days as ensouled. ${ }^{92}$ Hence the therapeutic abortion was accepted in the case of a fetus under this age.

To this point no one had attempted to set out a complete theoretical defense of therapeutic abortion or to distinguish it from contraception for medical reasons. Defense and distinctions were the work of the great Spanish specialist on marriage, the Jesuit Thomas Sanchez (1550-1610). His theory was highly dependent on his new analysis of the malice of contraception. It was always evil, he argued, to ejaculate semen and prevent it reaching the vagina, because man could not be trusted with "the administration of the seed," for the pleasure experienced was too great to make him a responsible administrator; he might seek this pleasure as his "sovereign good."93 There was, therefore, an absolute prohibition of acts preventing insemination in intercourse even if the acts were necessary for health. The sole exception was in the case of rape. Here the semen emitted was not in possession. To expel it lawfully the victim must act at once. If she did so, she acted as properly as a property owner who was entitled to pursue and strike a thief until he had reached a safe place. ${ }^{94}$ In this case, apparently, Sanchez believed.

${ }^{88} I d$. at 2.7 .8 , dealing with abortion by women who had conceived in fornication, adultery or incest. It is "homicide," but "it is not reputed homicide." In his earlier manual for confessors, he had provided interrogations on abortion.

89 Op. cit. supra note 86.

90 HURTER, op. cit. supra note 85, at 3.344-347.

91 Navarrus, Enchiridion seu Manuale Confessariorium et poenitentiarum, 3 Opera (Lyons, 1509) c. 25, n. 60-64, "The Sins of Physicians and Surgeons," 4. The printed gloss in this edition added, "John of Naples, St. Antoninus, Silvester, and commonly."

92 Navarrus, Consilia, 5.22, in 4 OperA (1591).

93 Thomas Sanchez, De sancto matrimonil sacramento (Venice, 1737) 9.17.15.

94 Id. at 2.22.17. 
there was no risk of abuse of conceding human beings power to dispose of the seed.

With these distinctions made, Sanchez could argue that while the prohibition of contraception was general, the prohibition of abortion had exceptions. The conceptus, in the intermediate state between being semen and being an ensouled human, was open to attack. Si aliquis applied only if the abortion was to hide sin or further lust. Where the mother would otherwise die, and the fetus was not ensouled, its killing, "more probably," was lawful.95 In this case, "the fetus invades, and, as it were, attacks." The fetus was described not as unjust, but as dangerous. Unlike contraception, there was no administration of the seed, no danger of "too great delight." Moreover, where contraception was urged for health, there was no present attacker, and the alternative of abstinence was available. Here, by hypothesis, destruction of the attacker alone could meet the danger. ${ }^{96}$

Having set up the strongest case, Sanchez considered three more difficult extensions. Suppose the girl had conceived in unlawful coitus and her relatives would probably kill her if they discovered that she was pregnant. Might she kill the fetus to save her life? Again Sanchez thought it more probable that she could. Suppose she was betrothed to one other than the man who had impregnated her, could not without scandal terminate the engagement, and ran the risk of bearing another's child to her husband. Could she avert the danger by destruction of the embryo? Sanchez believed she could.97 There was, too, no mortal sin in intercourse just after conception, where the medical biology of the day indicated that the risk of abortion was high. The intercourse itself was lawful; the loss of "the unformed matter" was not "such a great loss" as to be mortal sin. ${ }^{98}$ In contrast, if an abortion were merely to protect a girl's reputation, the peril was too remote, the fetus not an attacker, and abortion would be unjustified.99 It was apparent that once other values were allowed to be weighed against the embryo's life, fine scales indeed were necessary to make a just balance.

The subhuman character of the unensouled fetus authorized man to prefer other values to its existence. What of the ensouled fetus where medicines necessary for the mother's health would endanger it? Sanchez made a distinction. If the means "tended directly" to killing the embryo, as would its wounding or beating or the use of poisonous drugs directed to its death, they

o5 Id. at 9.20 .9 .

96 Id. at 9.20.8, 11-12.

97 Id. at 9.20 .11 .

98 Id. at 9.22. On this point Sanchez followed his Dominican contemporary PETER DR Ledesma, De magno matrimonlae sacramento (Venice, 1595) 64.1.4.

99 Id. at 9.20 .9 . 
were not lawful. Nor were they lawful if there were a doubt as to the ensoulment of the fetus, for "it is intrinsically evil to procure the death of the innocent or to expose oneself to the risk of doing so."100 But other means which endangered the embryo also served the health of the mother. These included the opening of her veins, the cleansing of the uterus, baths - all listed by Avicennas as abortifacient. Sanchez held that they were lawful even if they were equally directed to the killing of the fetus and the salvation of the mother, for she "principally intends her own life." She was not bound under pain of sin to prefer the embryo's physical life to her own. Charity did require that she sacrifice herself only if the child could be born and baptized and so assured of spiritual life; but that the infant could be born if the mother died "is very rare and morally impossible."101

- To justify his conclusion Sanchez invoked the passage from St. Thomas on the double effect of an act of killing which saved one's life. There was, it would seem, a failure to take this passage as far as it logically might have carried, for by itself it implied the rightfulness of any abortion necessary to save life. As necessarily must often happen in moral reasoning, Sanchez checked this logical implication by assigning a higher value to innocent life where the means used were such as only to harm it. The distinction he made was not logical, but the point at which he struck a balance; and by his statement on means which equally served the mother and killed the fetus, he made the intention of the mother, not the finis operis, decisive.

Sanchez buttressed this application of Thomistic principle by analogy drawn from the scholastic theory of the just war. In a just war, "when a city is burnt in which it is established that there are many innocent such as infants," the burning is lawful, "as experience teaches and as all state in the treatise on war." In the case proposed, "just war is waged against lethal humors by applying medicine." The argument was confirmed by commonsense analogy: If a pregnant woman were attacked by a bull, she could run though running caused an abortion; so here she could use the means necessary to save her life.

These illustrations, like Thomas Aquinas' original example, each involved an act where one end or intention of the act itself was the killing of an innocent human being. Another example of the same sort, approved by the acute Belgian Jesuit, Leonard Lessius, was the killing of an infant in escaping from an enemy threatening one's life. It was, Lessius taught, lawful to step on and kill an infant who was in the route of escape. He quoted Cajetan commenting on Thomas, "to kill the innocent per accidens, by doing a lawful and neces- 
sary act is not against a natural, divine, or human law."102 With this principle generally accepted, it was not a serious restriction on therapeutic abortion for Lessius to take a different path from Sanchez on the killing of the unensouled fetus. Not "condemning" the opinion of "our Sanchez," Lessius reached a different formal result in that case, because he did not accept the explanation Sanchez gave why contraception was prohibited. The common opinion of moralists was that contraception was wrong because it was "against the nature of generation." Accepting this approach, Lessius concluded that abortion was even more "against the nature of generation." Consequently, one could not deliberately act for this purpose. ${ }^{103}$ But the practical result was the same as Sanchez's, for Lessius simply extended to all therapeutic abortion what Sanchez had reserved for the ensouled embryo. For a mother to take medicine to save her life was lawful, provided the killing of the fetus was "beyond her intention." Indeed Lessius explicitly recognized that he thus reached the same result as Antoninus and Sylvester; what they meant, he said, was that the killing was lawful as long as there was no "direct intention" to kill. From the examples given, it was evident that "direct intention" was distinguished from "indirect intention" or killing "per accidens," not by the physical acts which were done, but by the dominant purpose of the mother; the intent to kill was indirect if the dominant purpose was to save her own life.

Almost a century and a half later, when St. Alphonsus Liguori made his masterly summation of the work of the casuists, he reached the conclusion of Lessius. Under the general heading, "Is it sometimes licit to kill the innocent?" and under the specific heading, "Is it sometimes lawful to procure an abortion?' he held that Sanchez's opinion permitting the intentional killing of the unformed fetus to save the mother was a probable opinion. But the "more common opinion" held that as it was never licit to expel the seed, even in rape, "so much less is it lawful to expel the fetus which is closer to human life." The more common opinion was "safer" and therefore to be followed. ${ }^{104}$ Moreover, there was no point to the first opinion because, "as our Father Busenbaum says, "Why take a drug directly to expel the fetus when one can, and it suffices, to expel it indirectly?" " The reference to Busenbaum was to the German Jesuit whose treatise on moral theology was the text taken by Liguori for his own exposition of doctrine. Busenbaum, quoted by Liguori,

\footnotetext{
102 Leonard Lessius, De iustitia et iURe (Lyons, 1653) 2.9.2.58. The quotation from Cajetan was taken from Cajetan, In summam theolocicam S. Thomas Aquinatis 2.2.76.2.

103 Lessius, 2.9.10.61.

104 Alphonsus Liguori, Thrologia moralis, in Opera omnia, ed. L. Gaudé 1905, Book 3, n. 394.
} 
had further taught that if it is judged that the mother of an ensouled embryo will die unless she takes medicine fatal to the fetus, "it is lawful to take it, and, according to some she is bound to take it, intending directly only her own health, although indirectly and consequently the fetus is destroyed."105

In principle, then, lawfulness turned on the mother's intention. But the logic of one principle never rules the solution of a complex moral problem. Like Sanchez, Liguori introduced the distinction of means "tending directly" to kill the fetus, such as blows and wounding, and held those illicit while allowing the cutting of the mother's veins, purging of her body, and baths. Moreover, the threat to the mother's life had to be immediate. The danger of death in childbirth was "far distant," the fetus was not a "present aggressor," and abortion was not justified to avert the danger; a fortiori, the danger of being killed by relatives was not justification for the mother. With these reservations stated, therapeutic abortion to save the mother from immediate danger was permitted; the intention to save her own life must predominate; only some means were permitted. The balance struck by the casuists and now set out by St. Alphonsus treated the embryo's life as less than absolute, but only the value of the mother's life was given greater weight.

Papal Legislation.-The tendency of casuistic examination of abortion had been to question the absolute prohibition. An opposite tendency, to reinforce the prohibition, may be discerned in the legislative activity of the papacy. The difference between legislation and speculation was at least as old as the Decretals of Gregory IX, where Si aliquis took a far stronger stand on abortion of the unformed fetus than the majority of contemporary theorists did. The same split may be observed in the nineteenth and twentieth centuries between legislative severity and theoretical hesitancy. The difference does not lie in the difference between canonists and theologians; instances of canonists on the softer speculative side and theologians on the harder legislative side are not rare. ${ }^{106}$ The difference seems to lie in the work being done. The tendency of the legislator has been prudential or paternalistic, seeking to safeguard as strongly, certainly, and absolutely as possible the rights of the embryo unable to defend itself.

In the period of the great casuists there were two bursts of this legislative prudence. One occurred in the reforming reign of Sixtus $\mathrm{V}$ and reflected not so much a prudential concern for the embryo as a split of judgment as

105 Idem.

106 See, for example, supra, p. 99-100, 101-02, the split on interpretation of Si aliquis. For later example note that the theologians of the Holy Office were taking a hard legislative line, while moralists were taking a soft speculative one, infra, p. 116-17, 121-22. 
old as Ancyra and Elvira. Although Si aliquis had been canon law for over three hundred years, the Sacred Penitentiary by the time of Gregory XIII did not treat as homicide the killing of an embryo under 40 days. Even where the embryo over $\mathbf{4 0}$ days was sinfully destroyed, the Penitentiary made less difficulty about dispensations than when an adult human was killed. The reason was not that the older embryo was regarded as subhuman, but the influence of the canon Sicut ex and the observation that an embryo was rarely killed in hatred. The cases regularly involved women who had conceived in fornication and killed to protect their reputations and men who counselled them to do so to save their own. Like Ancyra, the Penitentiary saw the motive of protecting reputation as extenuation. 107

Sixtus V had another view, the view of Elvira, that abortion as an adjunct to fornication intensified the evil. In the course of a campaign largely aimed at prostitution in Rome, on October 29, 1588, he issued the bull Effraenatam. The pope invoked Aliquando and asked rhetorically, "Who would not punish such cruel lust with the most severe punishments?" The bull went on to provide that all the penalties of both canon and secular law against homicide were to apply to those producing an abortion, whatever the age of the fetus, and to those practicing contraception by drug. The old exception on irregularity of Sicut ex was wiped out. No exception was mentioned for therapeutic abortion. Persons guilty of the crime were excommunicated, and absolution from the excommunication was reserved to the Holy See alone. ${ }^{108}$

Effraenatam was not an unqualified success. The reservation of absolution to the Holy See created administrative difficulties. The bull clashed with the practice of the Penitentiary and the theory of the canonists and theologians. Sixtus V had not been dead long when, in 1591, Gregory XIV restricted the bull. Noting suavely that "the hoped-for fruit" had not resulted, the new pope repealed all its penalties except those applying to a fetus which had been ensouled.109 The bull was not cited in the controversy on therapeutic abortion. The legislative incursion into the field had not changed the theologians' balance.

Almost a century later the papacy acted again in the area. Its intervention this time was the fruit of the efforts of conservative theologians centered at Louvain to check what they deplored as "laxism" in moral theology. ${ }^{110}$ After a theological and a cardinalatial commission had examined one hundred

107 Navarrus, op. cit. supre note 92, at 5.22.

108 Epfraenatam, Codicis iuris fontes, ed. P. Gasparri, vol. 1; p. 308 . On the bull's relation to prostitution, see NoONAN, op. cit. supra note 16, at 362-63.

109 Sedes apostolica, Codicis iURis fontes I, 330-331.

110 On the history of the Louvain efforts, see Francis Deininger, Joannes Sinnich: der Kampf der Louvener Universitat gegen den LaXismus 53 (Düsseldorf, 1938). 
propositions taken from a variety of theological treatises and delated to Rome by Louvain, the Holy Office under Innocent XI issued a condemnation on March 2, 1679. Sixty-five propositions were condemned, of which two related to abortion:

34. It is lawful to procure abortion before ensoulment of the fetus lest a girl, detected as pregnant, be killed or defamed.

35. It seems probable that the fetus (as long as it is in the uterus) lacks a rational soul and begins first to have one when it is born; and consequently it must. be said that no abortion is homicide.

The 65 propositions were globally designated by the Holy Office as "at least scandalous and in practice dangerous." 111 The censure, therefore, at the minimum bore on the prudence of teaching the propositions, not on their abstract truth. What were rejected was Sanchez's opinion that danger of death from relatives was ground for abortion and the opinion of "the prince of laxists," John Caramuel y Lobkowicz, on the time of ensoulment.112 The main line of casuistic thought on therapeutic abortion was unmentioned and unaffected. Outer limits of permissible teaching were, however, established in practice by the decree.

Opinion on Ensoulment.-A stream of thought distinct from papal authority also began in the seventeenth century, without immediate effect but with ultimate significance for the view of abortion. It came from medical doctors versed in philosophy. The title of the first work of the new approach summarizes its content: A Book on the Formation of the Fetus in which It Is Shown that the Rational Soul Is Infused on the Third Day. It was written by a physician at Louvain, Thomas Fienus, and appeared in $1620 .{ }^{113}$ A year later there was an even more influential treatise, Medico-Legal Questions, by a Roman physician, Paul Zacchias. In his learned treatise on medical aspects of the canon and civil law Zacchias attacked the prevailing interpretation of Aristotle which envisioned the fetus progressing by stages from vegetable ensoulment to animal ensoulment to rational ensoulment. This "metamorphosis of souls," he declared, was "an imaginary thing." 114 Belief that the rational soul was in fact instilled after forty days rested on no evidence that the rational soul was then

111 ENChIRIDION SYMBOLORUM DEFINITIONUM ET DEGLARATIONUM RE REBUS PIDEI ET MoRUm, ed. H. Denzinger, rev. Adolf Schonmetzer (Barcelona, 1963) (hereafter Denzinger).

112 John Caramuel y Lobkowicz, Theologia moralis fundamentalis libri (Lyons, $1675)$.

113 See (Anonymous) De animatione foetus, 11 Nouvelle Revue théologiQue 182 (1879).

114 Paul Zacchias, Quaestionbs Medico-Legales (Lyons, 1701) 9.1. 
in operation; nor could the movement of the fetus have any significance in showing the presence of a rational soul. Those who argued that there was a rational soul at some time in the embryo, but at some time after conception, were thus entangled in "absurdities" in trying to show the basis of their conviction. On the contrary, a true Thomistic view of the unity of man required that there be a single human soul from the beginning of the existence of a new fetus.115 The rational soul, Zacchias argued, must be "infused in the first moment of conception."116.

Zacchias' thesis on ensoulment was well received, and he himself in 1644 received from Innocent $X$ the grand title of "General Proto-Physician of the Whole Roman Ecclesiastical State." In 1658 Geronimo Florentinio of the Congregation of the Mother of God brought out a work entitled Baptisms of Doubtful Men, in which he argued that a fetus should be baptized if it was taken from the mother's womb before forty days. In the next thirty years the thesis of Florentinio was found unobjectionable by the theological faculties of Paris, Vienna, Prague, and Rheims. Delated to the Roman tribunal of the Index of Prohibited Books, the treatise was declared blameless if Florentinio added that no one was bound under pain of mortal sin to baptize a fetus under forty days. ${ }^{117}$

The theory of Zacchias had no immediate impact on the theologians dealing with abortion. He himself in answering objections to his novel proposition agreed that the "milder" opinion of the canons could be followed as to punishment for abortion of a fetus under forty days; a "greater injury" was done in killing an older embryo. ${ }^{118}$ The theologians themselves were slow to. respond to the new arguments. By the eighteenth century Constantino Roncaglia of the Congregation of the Mother of God contended in analyzing the sin of abortion that it was "most probable" that the fetus was ensouled at the instant of conception or "at least from the third or seventh day."119 But the leading moralist of the day, St. Alphonsus, declared that "some say badly" that the soul is infused at conception. ${ }^{120}$ He preferred to rely on the Septuagint translation of Exodus, which Zacchias had dismissed as "a commentary" which was not Scripture, and to hold it "certain" that there was not immediate ensoulment.

\footnotetext{
115 Id. at 9.5 .

$116 I d$. at 9.1 .

117 Op. cit. supra note 113 , at 182.

118 Zacchias, op. cit. supra note 114 , at 9.5 .

119 Constantino Roncaglia, Universale moralis theologia ad usum confesSARIORUM (Lucca, 1834) 11.1.2.3.

120 Liguori, Theologia moralis 6.394. Elsewhere, on baptism, he said that an aborted fetus was also to be baptized conditionally, "especially since today there flourishes the opinion, received not without approbation from experts, that the fetus from the beginning of conception, or at least after several days, is informed by a soul," 6.121 .
} 
Another trend with long-run, rather than immediate, implications was the growing cult of the Immaculate Conception of Mary and the increase in theological and papal support for this doctrine. Zacchias used the argument from its liturgical celebration in favor of his contention. The Catholic Church, he said, celebrated the conception of Mary, who was conceived according to the flesh; it did not celebrate the coming into existence of what was "brute, corruptible, and mortal."121 When, in 1701, Clement XI made the Immaculate Conception a feast of universal obligation in the Church, belief in immediate ensoulment of all human beings received indirect support and encouragement.

The three strands of thought - the pastoral-legislative interest in a sure and certain protection of the embryo, the medical-philosphical rejection of a "metamorphosis of souls" in the stages of fetal development, the popular liturgical devotion to the Immaculate Conception - all represented powerful impulses destined to affect the conclusions drawn by the casuists from their abstract and narrow consideration of cases of therapeutic abortion. As of 1750 , however, it was the balance struck by the casuists which dominated the teaching on abortion.

\section{Care from Conception, 1750-1965}

IN THE course of the next two centuries the teaching of the Church developed to an almost absolute prohibition of abortion. This development represented a substantial return to the patristic prohibition without the glosses and exceptions written in by casuistry; but it was not a naive invocation of the past; it was a conscious rejection of some solutions which had once been appealing. Hence, it was development - a testing of principles by human experience in the light of the Gospel and a reformulation of doctrine after this testing. Like other developed Christian teaching on slavery, on the rights of labor, on war, it embodied a sensitivity to certain values affirmed in the Gospel but not made effective in Roman, medieval, or post-Reformation culture.

In the formation of teaching the pastoral interest of the papacy played a strong part; and it was the central authority of the Church, far more prestigious in moral matters in the period 1880-1950 than ever before in its history, which dominated the development. The moral theologians and canonists bent to the papal leadership which, while reflecting the view of moral theologians, incorporated a broader sense of situation and likely trends and dangers. In 1588 Sixtus V, the most energetic of popes, could do nothing to

121 Zncchlas, op. cit. supra note 114 , at 9.5 . 
change the views of the dominant moralists; beginning with the papacy of Leo XIII the moralists, in this area of thought, followed the papal lead.

Sensitivity to Life.- The pastoral concern to protect the embryo was particularly animated by the spread of abortion in Western Europe. As early as 1795, the Marquis de Sade had attacked restrictions on abortion as the result of religious superstition and had exulted in the delight of destroying an embryo.122 His book, the first in Western Europe to praise abortion, carried a revolutionary destructiveness to the ultimate, and his special temper was not universal; but in a similar spirit of freedom from religious bonds, many Frenchmen practiced birth control during the last quarter of the eighteenth century, and the French birth rate declined precipitously. ${ }^{123}$ While contraception by coitus interruptus probably accomplished much of the reduction, it was the opinion of observers that abortion often supplemented ineffective contraception. ${ }^{124}$ By the twentieth century, the number of abortions, though hard to establish because of their criminal and therefore secret character, was believed to be large in such nominally Christian countries as France, Switzerland, and Italy. ${ }^{125}$

Against the current in favor of abortion, the Church reacted. In part, its position became sharper and stronger because of a development of the teaching on ensoulment. The Aristotelian interpretation of gestation, which supposed a transformation from vegetable soul to rational soul occurring in the embryo, had become obsolete. Even in the eighteenth century medical opinion had rejected it. ${ }^{126}$ In the nineteenth century the theologians, who had been slow to surrender a theory with so many famous supporters, inclined now to the idea of Zacchias. But both theological and biological developments affected their confidence in the old forty-day - eighty-day formula. In 1854 Pius IX proclaimed as a dogma of the Catholic Church that Mary was free from sin "in the first instant of her conception." 127 The new dogma dealt the old formula a glancing if not fatal blow. Meanwhile,

\footnotetext{
122 Atphonse de Sade, La philosophie dans le boudotr c. 2. De Sade, in passing, contended that France was overpopulated and that the "Chinese" practice of abandoning infants was desirable; but these themes were subordinated to his general celebration of unrestrained lust and cruelty as rational.

123 Charles H. Pouthas, la Population française pendant la premiere moitié DU 19e SiĚche 21 (Paris, 1956).

124 Jacques Bertillon, la Depopulation de la France 240-44 (Paris, 1911).

125 See, e.g., Robert Talmy, Historie du mouvement familial en France 1896-1939, at 106, 210-12 (Aubenas, 1962); Federico Marconcini, Culle vuote 210-11 (Alba, 1945); Bishops of Switzerland, Le Droit a la vie; 55 Documentation catrholigue 205 (1958).

126 See op. cit. supra note 113 , at 184.

127 Pius IX, Ineffabilis Deus, Denzinger 1641.
} 
educated European opinion could not accept Aristotelian biology in the light of the new discoveries in biology. Baer in 1827 had discovered the ovum in the human female; by 1875 the joint action of spermatozoon and ovum in generation had been determined. A change in organism was seen to occur at the moment of fertilization which distinguished the resultant from the components. It was easier to mark this new organism off from the living elements which had preceded it than it was to mark it off from some later stage of its organic growth in the uterus. If a moment had to be chosen for ensoulment, no convincing argument now appeared to support Aristotle or to put ensoulment at a late stage of fetal life.

The slowly changing attitude can be seen in the standard works. The most popular manual for seminary instruction in the nineteenth century was the Compendium of Moral Theology of the French Jesuit, John Gury. The book was largely a succinct presentation of St. Alphonsus Liguori, and in midnineteenth century Gury said, "The fetus, although not ensouled, is directed to the forming of man; therefore its ejection is anticipated homicide."128 In 1869, in the constitution Apostolica Sedis, Piux IX dropped the reference to the "ensouled fetus" in the excommunication for abortion, so that the excommunication now seemed to include the abortion of any embryo. An implicit acceptance of immediate ensoulment was found in the action: "otherwise it would be making an old law more onerous, which is contrary to the intent of the constitution."129 Thereafter, Thomas Gousset in his work for the practical instruction of confessors treated immediate ensoulment as the opinion - to be followed, so that all abortions were homicides. ${ }^{130}$ Augustine Lehmkuhl, the German Jesuit who was perhaps the ablest of the nineteenthcentury moralists, taught that abortion is "true homicide," "as follows from what is today the more common opinion that teaches that every fetus is ensouled with a rational soul." 131

In the twentieth century vigorous champions of the old theory could still be found. The most influential was Arthur Vermeersch, the Belgian Jesuit who was to be the principal draftsman of Casti connubii. No "solid arguments," he maintained, proved the immediate infusion of the soul. ${ }^{132}$ However, a more modern writer and the most persuasive of moral theologians of postwar

128 John Gury, Compendium throloota moralis (1864 ed), "De praeceptis decalogi," n. 402.

129 Loc. cit. supra note 113, at 186. A commentary on Apostolicae Sedis in the same magazine (p. 331), however, contended that the old distinction stood.

130 Thomas Gousset, Théologie morale $\lambda$ L'usage des curés et des confesseurs n. 621 (Paris, 1874 ed.).

131 Augustine Lehmkuhl, 1 Theolooin moralis n. 840 (Freiburg i. Br., 5th ed. 1888).

132 Arthur Vermeersch, 2 Thbolocia moralis n. 622 (Bruges, 1924). 
Europe, Bernard Häring, taught that the teaching of Aristotle had but "slight probability" and that, consequently, "every abortion is murder."133 In keeping with this approach, Häring condemned as abortion the use of intrauterine devices if their use was to prevent nidation of the fertilized ovum. ${ }^{134}$ As long as contraception was not accepted by the Church, the time of ensoulment did not determine whether a sin was committed. If some form of contraception were to be accepted by the Church, the line between contraception and abortion would be highly important to draw. The tendency, reflected by Häring's work, was to draw the line at conception.

The changed view of ensoulment could be seen as part of a broader humanistic movement of the nineteenth and twentieth centuries to be more sensitive to the value of life. This sensitivity, indeed, was heightened as more terrible ways of destroying life were perfected. In the twentieth century much of the old casuistry on killing appeared obsolete because of its narrow focus on a few facts of a case and its insensitivity to life. In particular, the Catholic teaching on the just war which had provided a substantial analogy for abortion began to be questioned. By 1965 the Second Vatican Council could call for an "examination of war with an entirely new mind" and to declare the indiscriminate bombing of cities (which had been a usual act in World War II) to be "a crime against God and man."135 In the very long run, the slowly shifting approach to what was lawful in the killing of adults would presumably have a reinforcing effect on the Church's desire to protect embryonic life.

Papal Rulings.-To speak of this twentieth-century trend is to anticipate. In the period between 1850 and 1965, the pastoral activity of the papacy carried the main burden of protective measures. It acted through the canon law, through the rulings of the Holy Office, and through public teaching. The 1869 extension of excommunication, the final sanction of the Church, has been noted. The new Code of Canon Law in 1917 made a further extension. Because of the special phrasing of the original bull of excommunication, Effraenatam of Sixtus V, it had been argued that the excommunication did not apply to the mother herself who sought or consented to an abortion, although it did to the doctor and other principals in abortion. ${ }^{136}$ In 1917 the new Code of

\footnotetext{
133 Bernard Häring, 3 The Law of Christ 206, trans. by Edward Kaiser from the 7 th German edition, 1966.

134 Idem.

135. Second Vatican Council, Gaudium et spes 80.

136 The prevailing view was that Effraenatam intended to apply to the mother, but that as the opposite interpretation was "probable," the benign view had to be observed in practice. "Avortement," 1 Dictionnaire de thÉologie Catholique 2651.
} 
Canon Law specifically included "mothers" in those excommunicated for procuring an abortion. ${ }^{137}$

A hardening position on the medical cases was initiated with a series of responses from the Holy Office running from 1884 to 1902 . The old casuistry on therapeutic abortion had existed in the teeth of Effraenatam which, by its terms, made no exceptions. In the midst of keen debate in Roman theological circles, the Holy Office began to eliminate the exceptions. After consideration of the case for several years, it declared in 1889 that it was not "safe" to teach in Catholic schools that a craniotomy necessary to save the mother's life was lawful, although without it both mother and child would die. ${ }^{138}$ It extended this ruling to any operation "directly killing the fetus."139 In 1895 it dealt not with the "safeness" of teaching but the moral "safeness" of an actual operation. The question asked of it concerned a doctor who, to save a mother from "certain and imminent death," used means which do not "per se and directly tend to the killing of the fetus in the maternal breast but act only so that the fetus will, if possible, be extracted alive, although it will soon die as it is entirely immature." The Holy Office declared that the operation might not safely be performed; on July 25,1895 , this answer was personally approved by Leo XIII. ${ }^{140}$

In 1898 the Holy Office declared that if birth was not possible because of the mother's "tightness," it was not licit to provoke an abortion. Where there was an extrauterine pregnancy, a laparotomy was lawful "to extract the ectopic conceptus from the breast of the mother, provided that, to the extent possible, serious and appropriate provision is made for the life of the fetus and mother."141 Was it lawful, the theologians of Montreal asked, to extract an ectopic fetus under six months? In 1902 the Holy Office answered, "No, according to the decree of May 4, 1898, by force of which the life of the fetus, to the extent possible, must be seriously and appropriately provided for." It added that both decrees meant that the operation could not be performed except at a time and by means according to whose "ordinary results"

137 CODEX JURIS CANONYa, c.2350. Canon 985 suspends any priests procuring abortion of a "human fetus."

138 To the Archbishop of Lyons, May 31, 1889. Denzinger, n. 1889. As recently as November 28, 1872, the Sacred Penitentiary, when asked if a craniotomy could be actually performed, had answered, "Consult approved authors, old and new, and act prudently." Old approved authors like Sanchez probably could have been interpreted to authorize the operation to save the mother's life.

138 To the Archbishop of Cambrai, August 19, 1889. Denziger 1890. The questions, submitted in 1886, are printed in full in T. Lincoln Bouscaren, Ethics of Ectopic Operations 183-86 (1933).

140 To the Archbishop of Cambrai, July 24, 1895. Denzinger 1890a.

${ }^{141}$ To the Archbishop of Sinaboa, Mexico, May 4, 1898. Denzinger 1890b. 
both lives would be provided for. ${ }^{142}$ If this decree were taken literally, even the ectopic exception to the abortion rule was eliminated.143 Read together, the Holy Office decrees turned back even the most appealing exceptions to the inviolability and independent integrity of the embryo.

The Holy Office decrees, in the first instance, instructed bishops and theologians, and only through them the priests and people; considerable caution was urged by the theologians on confessors in disturbing the good faith belief of doctors performing therapeutic abortions that they were acting rightly. ${ }^{144}$ A split developed between the teaching of the theologians and the medical schools. In 1924 the leading Catholic moralist Vermeersch recognized this conflict and wished for "perspicuous statements of authority by which the consciences of Catholics could be firmly directed."145 This supposed need to speak forcefully to Catholic doctors formed part of the pressure for a papal statement, which was in fact made in 1930. There were also general reasons for a public statement to a wide audience. Advocates were now appearing for the right of women to dispose of the fetus as part of her body; abortion was seen by some as a liberty of the modern woman. ${ }^{146}$ In revolutionary Russia abortion had been legalized; other countries were considering permissive legislation. To dissipate the doubts of Catholic doctors, to answer the champions of abortion, to speak to the legislators, to reach the widest possible audience, it seemed necessary for the pope to speak. The opportunity was presented when specifically responding to the new Anglican teaching on contraception, Vermeersch and Francis Hürth prepared an encyclical on Christian marriage. This small summa on Christian marriage, a synthesis of many basic theses of Christian teaching on human sexuality, was issued by Pius XI on December

\footnotetext{
142 To the Dean of the Faculty of Theology of the University of Montreal, March 5, 1902. Denzinger 1890c.

143 The morality of aborting an ectopic pregnancy had been presented by three of the six questions raised by the Archbishop of Cambrai in 1886. The general, negative response by the Holy Office in 1886 had made no distinction between abortion in this case and other cases of therapeutic abortion. In 1892, however, the morality of the ectopic case was debated as a "new" question in the Ecclesiastical Review. Joseph Aertyns denied that abortion was lawful here, Ecclesiastical Review 10.62; Thomas Sabetti argued that the ectopic fetus could be treated as a "materially unjust aggressor" and destroyed, ibid. 9.347; Lehm; kuhl defended the practice as "indirect" abortion, ibid. 10.62. The controversy continued in Rome with A. Eschbach, rector of the French Seminary in Rome, attacking Lehmkuhl for not accepting the Holy Office decisions of 1884, 1886 and 1889, "Casu de ectopicus sen extra-uterinus conceptus," 2 ANALECTA ECCLEsiastraA 88 (1894). Lehmkuhl vigorously defended himself, $i d$. at 220 and 321 . When the 1895 decree appeared, the editors of Analecta ecclesiastica asserted that the question had been decisively determined against Lehmkuhl, ibid. 3.482. The question, however, was not explicitly answered until 1902, and the 1902 decree did seem to foreclose all discussion. But, as will be seen, this was not the last word.

144 See LehMKUHL, op. cit. supra note 131 , at $\mathrm{n} .1002$.

145 VERMEERSCH, op. cit. supra note 132 , at $n$. 630.

146 Havelock Ellis, 6 Studies in the Psycholocy of Sex 607 (1924).
} 
31,1931 . It contained sharp condemnation of abortion in general and of abortion as practiced by three specific kinds of people.

The encyclical spoke of "that most grave crime by which the offspring hidden in the maternal breast is attacked." Speaking first of those who justified it by medical and therapeutic indications, the pope asked,

What cause can ever avail to excuse in any way the direct killing of the innocent? For it is a question of that. Whether it is inflicted on mother or on offspring, it is against the commandment of God and the voice of nature, "You shall not kill. The life of each is sacred."

The argument that the state could authorize the taking of life did not apply; the state had power only over criminals. The argument that the mother could treat the fetus as an unjust aggressor did not apply, "for who will call an innocent little one an unjust aggressor?" As for what had been the usual defense in writers such as Sanchez, the encyclical, without adverting to contrary authority, simply denied that "there is a law of extreme necessity which can lead to the direct killing of the innocent." 147

Then there were those who practiced abortion in marriage to prevent offspring. They were described as "wicked." Against them Pius XI invoked the ancient words of Aliquando and upbraided them for their "lustful cruelty" or "cruel lust.". 148

Finally, there were the advocates of abortion on social and eugenic grounds. Their arguments were analyzed as saying that some persons could be involuntarily sacrificed for the good of others. The "killing of the innocent" for such reasons was "contrary to the divine commandment promulgated also by the words of the Apostle, "Evils are not to be done in order that good comes from them." "Like St. Thomas on the "salvific abortion" of a fetus to baptize it, Pius XI invoked Romans 3.8, which was now given the status of a divine command. The independent destiny of the fetus, not to be destroyed for its own good or the good of others, was thus asserted.

The encyclical showed considerable concern with the actions of public authority. German law, in particular, had made a doctor liable if he did not save the mother by a therapeutic abortion. ${ }^{149}$ Not referring to this by name the pope observed that public authority could not confer a right to dispose of innocent life. Rather, the legislators had a serious obligation to defend the innocent by "laws and sanctions." They were prophetically re-

I47 Prus XI, Casti connubir, Acta apostolicae sedis 22.562 (1930).

148 Id. at 563.

149 Vermeersch had remarked on the law (German Criminal Code, art. 222) in 2 TheoLOOIA MORALIS n. 630 . 
minded that if they permitted embryos to be killed by doctors or others, "God is judge and avenger of the innocent blood which cries from earth to heaven." 150

In this compact and sweeping statement, the tones of early Christianity were heard: embryonic life was sacred; God and man were grievously offended by its destruction; there was no exception. The strongest and most comprehensive denunciation of abortion made by papal authority, it did not constitute infallible teaching; but, addressed to the bishops of the whole Church and authoritatively proclaiming the moral law, it was of controlling force for Catholics.

The central teaching authority found one occasion to reaffirm its stand. Twenty years later, legalized abortion had swept Japan, while the advocates of legalized abortion were beginning to resume their work in postwar Europe. At the same time the Church was opening its stand on contraception by permitting the systematic avoidance of conception by the use of rhythm. In the first papal address to definitively approve this system, the difference between it and both contraception and abortion was emphasized. In the allocution, addressed to the Italian Catholic Society of Midwives on October 29, 1951, Pius XII taught:

The baby in the maternal breast has the right to life immediately from God. - Hence there is no man, no human authority, no science, no medical, eugenic, social, economic or moral "indication" which can establish or grant a valid juridical ground for a direct deliberate disposition of an innocent human life, that is a disposition which looks to its destruction either as an end or as a means to another end perhaps in itself not illicit. - The baby, still not born, is a man in the same degree and for the same reason as the mother. ${ }^{151}$

A more succinct and complete assertion of the rights of the embryo had not been made.

The Second Vatican Council had reason to consider abortion specifically in relation to family planning. In its pastoral constitution, Joy and Hope, on the Church in the modern world, the Council had affirmed the duty of responsible procreation, of conscientious decision making by spouses as to how many children they should have. The Council had also affirmed that conjugal love was "perfected" in conjugal intercourse. It then had recognized that there might well be a conflict between the expression of love and respon-

150 Prus XI, op. cit. supra note 147 , at 564 .

151 Pius XII, Address to the Italian Catholic Society of Midwives, Acta Apostolicar sEDIs 43:838-39 (1951). The draftsmen of this statement were the German Jesuits Hürth and Lieber, according to an interview I have had with Father Lieber. 
sible parenthood. ${ }^{152}$ The Council, carefully refraining from a decision on contraception, did not attempt to solve the conflict. It did observe, however, "These are those who presume to offer to these problems indecent solutions; indeed they do not shrink from killing." In response to such solutions, the Council declared, "Life from its conception is to be guarded with the greatest care. Abortion and infanticide are horrible crimes."153

In this declaration the Council made several doctrinal advances. For the first time contraception was treated differently from abortion. A line was drawn, with contraception on one side, abortion and infanticide on the other. Certain commands on contraception were specified as being for "children of the Church." The teaching on abortion, in contrast, was in a document otherwise addressed to "all men of good will." Abortion was condemned; no final judgment was made on all forms of contraception. Beyond these distinctions, an amendment, specifically made and adopted, added the words "from its conception." 154 In this way the Council sharply marked off the status of the conceptus from the status of spermatozoa and ova. Finally, the declaration was the first statement ever made by a general council of the Church on abortion; its judgment, promulgated by Paul VI on December 5, 1965, represented a commitment by the Catholic bishops of the world to care from conception.

Exceptions.-In three successive stages then-decision by Roman congregations, teaching by popes, affirmation by pope and general council - authority had intensified the opposition of the Church to abortion. Exceptions, however, still survived, and it is essential to understand these exceptions to understand the balance now struck. Their survival may perhaps be best followed in the changing use of "direct" and "indirect." Lehmkuhl used "direct" in the sense in which Thomas had used it in justifying an act of killing in selfdefense. As late as 1886 he taught that to procure an abortion to save the mother's life was "scarcely a direct abortion in a theological sense, any more than yielding a plank in a shipwreck to a friend is direct killing of oneself."155 In this sense "direct" was equated with what was intended by the person acting. Yet, like Liguori, Lehmkuhl found some means objectionable whatever the person's intention. He restricted permissible direct abortion to the

152 Second Vatican Council, Gaudium et spes, secs, 47-50.

153 Id. at sec. 51.

154 Second Vatican Counarl, Schema constitutionis pastoralis, De ecciesia in Mundo HUIUS TEMPORIS : Expensio modorum pt. 2, p. 36, n. 101 (1965). The words "in utero" were struck because of the objection that "the fertilized ovum, although not yet in the uterus is sacred." In striking this language, the drafting committee said, "the time of animation is not touched on."

155 LEHMKUHL, op. cit. supra note 131 , at 841 . 
removal of the immature fetus from the embryo, but condemned craniotomy entirely. As in Liguori, the basis for the distinction between means was not clear, because to consider means in some way meant to judge the act of killing on the basis of the finis operis, rather than by the intention of the person performing the act. Lehmkuhl attempted to distinguish by saying that where the fetus was removed there was an act with a double effect - on the one hand, the good effect of removing a danger to the mother with the additional benefit of opportunity to baptize the fetus; on the other hand, the bad effect of "acceleration of the death of the fetus." The good, he contended, outweighed the bad, and the bad effect was not a means of achieving a good end. In contrast, in craniotomy the fetus was killed at once, and the good effect, the removal of danger to the mother, followed from the act of killing. It is apparent that this analysis rested on a distinction without foundation in the example from St. Thomas where the act of killing was the means of selfdefense in the same way that the craniotomy simultaneously saved the mother and removed the fetus.

Lehmkuhl's opinion permitting therapeutic abortion as indirect was rejected by the Holy Office in the decree approved July 25, 1895. As late as 1931, however, the meaning of "direct" which he had used was invoked by Ernesto Pestalozzi, director of the Obstetrical-Gynecological Clinic of the University of Rome. Writing in the Vatican newspaper, Osservatore Romano, three weeks after Casti Connubii, he contended that Pius XI had not condemned the usual practice of Italian physicians in procuring an abortion "to save the mother from very serious danger." Such a procedure, where the doctor's intention was to save the mother, was not a "direct killing of the innocent" condemned by the encyclical. Pestalozzi's effort was treated by the theologians as a gross misinterpretation of Casti connubii. ${ }^{156}$ In the half century since Lehmkuhl had written, "direct" was applied to any means used to abort a normal fetus, with whatever intention it was done.

There were two cases, however, which received special consideration. One was the case of an ectopic pregnancy, the other of a cancerous uterus. Despite the Holy Office decree of 1902, Lehmkuhl refused to accept defeat on the moral propriety of terminating an ectopic pregnancy. He now argued that it was lawful to remove the tumor which "sometimes appears in various organs of the mother" from the ovum being outside the uterus. He did not make clear whether the tumor was "the swelling of the tube quite independent of the pregnancy or whether the mass growing in the tube was the result of

156 The substance of Pestalozzi's article, and theologicar reaction to it, are set out in Agostino Gemelli, De l'avortement indirect, 60 Nouvelle revue théologrque 509 (1933). 
the pregnancy itself." $157 \mathrm{He}$ argued that the removal of the tumor was an indirect, permissible abortion. Like his distinction between craniotomy and removal of a normal fetus, Lehmkuhl's distinction appeared to attach the term "indirect" to a means which brought about fetal death gradually; that he could still use this distinction after the Holy Office decrees and win supporters for it from the moral theologians reflected a willingness to treat the ectopic pregnancy differently. In the 1920's and into the 1930's, the moralists continued to be divided. ${ }^{158}$ No one supposed, however, that Casti connubii had decided the case. The distinction which won more support than Lehmkuhl's was argued by Bouscaren as follows: In the case of an ectopic pregnancy in the Fallopian tube, the tube became pathological. An operation to remove the tube was lawful like other surgery. The fetus was not the direct object of the operation; its indirect killing was justified whenever there was "a notably greater probability of saving the mother's life."159 In this usage "direct" was applied to the intention of the physician to remove the pathological condition. As to the physical act of removal, it had the good effect of removing the pathological tube, the bad effect of killing the fetus. Neither effect considered in itself was more "direct" than the other; but the intention of the physician was said to be directed only to the good end.

An analogous solution had been proposed by Lehmkuhl and unchallenged by the Holy Office in the case of the cancerous uterus. The removal of the uterus was said to be a moral act to remove a pathological condition; the death of the fetus it contained was indirectly accomplished. ${ }^{160}$ This analysis was seriously questioned after Casti connubii by Agostino Gemelli, the Franciscan biologist who was rector of the Catholic University of the Sacred Heart in Milan. Vermeersch defended Lehmkuhl's position, arguing that it was a standard case of double effect: removal of the fetus and removal of the cancer with the good effect outweighing the bad. ${ }^{161}$ He was pressed by Gemelli to deny that the bad means, the death of the fetus, was not the means used to the good end of the mother's health, and so forbidden by the principle that evil might not be done to achieve good. Surely, Gemelli contended, who wills the means wills the consequences even though he might prefer one of the consequences might not occur. ${ }^{162}$ Vermeersch replied with

157 This is the critical description of Lehmkuhl's presentation given by Bouscaren, $o p$. cit. supre note 139 , at 33 .

158 The manuals of Noldin-Schmitt (2.341) and Sabetti-Barrett (273) decided the operation to be lawful. Vermeersch hesitated in his 1924 edition, but decided in favor of the operation in his 1928 edition (Theologia moralis n. 628). See Bouscaren at 31-32.

159 Bouscaren, op. cit, supra note 139 , at 167.

160 LEHMKUHL (1910 ed.), op. cit. supra note 131, at n. 1010.

161 Vermeersch, Avortement direct ou indirect, 60 Nouvelle RevUe THÉoloorque 600 (1933).

162 Gemelli, op. cit. supra note 156 , at $520-27$. 
a new criterion of means to an end: Could a similar act be done without killing a fetus? The cancerous uterus, he argued, could be morally removed if it were empty; the operation did not become immoral by the presence of a fetus into the uterus, because the operation, not the death of the fetus, was the means to the end. ${ }^{163}$ Gemelli attacked this reasoning as too abstract. Concretely, when a hysterectomy was performed on a pregnant uterus, the fetus was killed; concretely, the death of the fetus was a means used to achieve health for the mother. It was, therefore, a direct killing, condemned by the encyclical. ${ }^{164}$

The vigorous debate between Gemelli and Vermeersch illustrated the ambiguity and question-begging involved in arguing about what was "direct"; and not surprisingly, neither moralist convinced the other. If an act whose finis operis was to kill a fetus was always wrong, Gemelli was right, and the killing was to be condemned. On the contrary, if such an act was sometimes lawful for the purpose of saving the mother's life, Vermeersch was right; but to show that he was right it was necessary to admit that there were cases where the balance of values was in favor of abortion. Vermeersch was unwilling to make this admission in so many words. In fact, even after the severe condemnation of Casti connubii, Vermeersch and other leading Catholic moral theologians admitted the lawfulness of killing the fetus in the two special situations of ectopic pregnancy and a cancerous uterus. Their position was puzzling and irritating to their critics because they used terminology inadequate to convey what they were doing.

What the theologians were doing was drawing a line. Line-drawing is the ordinary business of moralists and lawmakers. It says that up to a certain point such-and-such a value will be preserved, but after that point another value will have play. Line-drawing brings charges of inconsistency of principle only from a critic who believes that one value should not have any limits. The proper criticism of line-drawing, however, is not that it is inconsistent, but that the line is drawn at the wrong place; usually, indeed, charges of "logical inconsistency" are simply disguises for real objections to where the line has been fixed. ${ }^{165}$ In the case of abortion Catholic moralists wanted to draw a line so tightly fixed in favor of the fetus that abortion could be rarely justifiedjustified indeed only when there was an unusual extra circumstance added such as a cancerous uterus or an ectopic pregnancy. The permission of these two exceptions was consistent with the desire to establish a general rule of in-

163 Vermeersch, Une courte conclusion, 60 Nouvelle ReVUe théologrue 695 (1933).

164 Gemelli, Encore l'avortement indirect, 60 Nouvelle RevUe théologreue 693 (1933).

165 E.g., "Catholic reasoning on the subject of therapeutic abortion is inconsistent with its own principles." Glanville Williams, The Sanctity of Life and the Criminal. LAw 704 (1957). 
violability for the fetus; they were inconsistent only with an absolue valuation of fetal life.

As exceptions were admitted, why not more exceptions? The reason was lest the exceptions eat up the protection of the embryo. Vermeersch discussing the ectopic pregnancy observed sadly, "It is not without soulful solicitude that we weigh cases where, whether you embrace the benign or severe solution, what must be said is often at least indirectly dangerous to human lives."166 The consciousness that all but the most special exceptions would be pushed further weighed heavily. With one excusing cause, men would be led to seek others; insist on preserving both mother and child and maximum efforts would be made to save both. ${ }^{167}$ Trying to reach a point where maximum protection was afforded the fetus, the decision was made to except only the two unusual cases. ${ }^{168}$

\section{Conclusion}

The most fundamental question involved in the long history of thought on abortion is: How do you determine the humanity of a being? To phrase the question that way is to put in comprehensive humanistic terms what the theologians either dealt with as an explicitly theological question under the heading of "ensoulment" or dealt with implicitly in their treatment of abortion. The Christian position as it originated did not depend on a narrow theological or philosophical concept. It had no relation to theories of infant baptism. ${ }^{169}$ It appealed to no special theory of instantaneous ensoulment. It took the world's view on ensoulment as that view changed from Aristotle to Zacchias. There was, indeed, theological influence affecting the theory of ensoulment finally adopted, and, of course, ensoulment itself was a theological concept, so that the position was always explained in theological terms. But the theological notion of ensoulment could easily be translated into humanistic language by substituting "human" for "rational soul"; the problem of knowing when a man is a man is common to theology and humanism.

166 VERMEERSCH, op. cit. supta note 132, at n. 630.

167 Id. at n. 623.

168 Bouscaren cited figures showing that roughly $1 \%$ of observed pregnancies in the 1920's were ectopic pregnancies. BousCAREN, op. cit. supra note 139, at 102.

169 According to Glanville Williams (op. cit. supra note 165 , at 193), "The historical reason for the Catholic objection to abortion is the same as for the Christian Church's historical opposition to infanticide: the horror of bringing about the death of an unbaptized child." This statement is made without any citation of evidence. It is a piece of imagination, plausible but untrue. As has been seen, the Christian opposition to abortion began in the first century, when infant baptism was unknown. As has also been seen, desire to administer baptism could, in the Middle Ages, even be urged as a reason for procuring an abortion. It is highly regrettable that the American Law Institute was apparently misled by Williams' account and repeated after him the same baseless statement. See American Law Institute, Model Penal Code: Tentative Draft No. 9 (1959), p. 148, n. 12. 
If one steps outside the specific categories used by the theologians, the answer they gave can be analyzed as a refusal to discriminate among human beings on the basis of their varying potentialities. Once conceived, the being was recognized as man because he had man's potential. The criterion for humanity, thus, was simple and all-embracing: if you are conceived by human parents, you are human.

The strength of this position may be tested by a review of some of the other distinctions offered in the contemporary controversy over legalizing abortion. Perhaps the most popular distinction is in terms of viability. Before an age of so many months, the fetus is not viable, that is, it cannot be removed from the mother's womb and live apart from her. To that extent, the life of the fetus is absolutely dependent on the life of the mother. This dependence is made the basis of denying recognition to its humanity.

There are difficulties with this distinction. One is that the perfection of artificial incubation may make the fetus viable at any time: it may be removed and artificially sustained. Experiments with animals already show that such a procedure is possible.170 This hypothetical extreme case relates to an actual difficulty: there is considerable elasticity to the idea of viability. Mere length of life is not an exact measure. The viability of the fetus depends on the extent of its anatomical and functional development. ${ }^{171}$ The weight and length of the fetus are better guides to the state of its development than age, but weight and length vary. ${ }^{172}$ Moreover, different racial groups have different ages at which their fetuses are viable. Some evidence, for example, suggests that Negro fetuses mature more quickly than white fetuses. ${ }^{173}$ If viability is the norm, the standard would vary with race and with many individual circumstances.

The most important objection to this approach is that dependence is not ended by viability. The fetus is still absolutely dependent on someone's care in order to continue existence; indeed a child of one or three or even five years of age is absolutely dependent on another's care for existence; uncared for, the older fetus or the younger child will die as surely as the early fetus detached from the mother. The unsubstantial lessening in dependence at viability does not seem to signify any special acquisition of humanity.

A second distinction has been attempted in terms of experience. A being who has had experience, has lived and suffered, who possesses memories, is more human than one who has not. Humanity depends on formation by

170 E.g., R. L. Brinster and Joan L. Thomson, Development of Eight-Cell Mouse Embryos in Vitto, 42 Experimental Cell Research 308 (1966).

171 J. Edgar Morison, Fetal and Neonatal Pathology 99-100 (1963).

172 Peter Gruenwald, Growth of the Human Fetus, 94 American Journal of Oastetrics AND GyNeCOLOGY 1112 (1966).

173 Morison, op. cit. supra note 171, at 101. 
experience. The fetus is thus "unformed" in the most basic human sense. 174

This distinction is not serviceable for the embryo which is already experiencing and reacting. The embryo is responsive to touch after eight weeks $^{175}$ and at least at that point is experiencing. At an earlier stage the zygote is certainly alive and responding to its environment.176 The distinction may also be challenged by the rare case where aphasia has erased adult memory: has it erased humanity? More fundamentally, this distinction leaves even the older fetus or the younger child to be treated as an unformed inhuman thing. Finally, it is not clear why experience as such confers humanity. It could be argued that certain central experiences such as loving or learning are necessary to make a man human. But then human beings who have failed to love or to learn might be excluded from the class called man.

A third distinction is made by appeal to the sentiments of adults. If a fetus dies, the grief of the parents is not the grief they would have for a living child. The fetus is an unnamed "it" till birth, unrecognized as personality by its own parents. The lack of feeling for a fetus is an index of its subhuman state.

Yet feeling is notoriously an unsure guide to the humanity of others. Many groups of humans have had difficulty in feeling that persons of another tongue, color, religion, sex, are as human as they. Apart from reactions to alien groups, we mourn the loss of a ten-year-old boy more than the loss of his one-day-old brother or his 90 -year-old grandfather. The difference felt and the grief expressed vary with the potentialities extinguished, or the experience wiped out; they do not seem to point to any substantial difference in the humanity of baby, boy, or grandfather.

Distinctions are also made in terms of sensation by the parents. The embryo is felt within the womb only after about the fourth month. ${ }^{177}$ The embryo is seen only at birth. What can be neither seen nor felt is different from what is tangible. If the fetus cannot be seen or touched at all, it cannot be perceived as man.

Yet experience shows that sight is even more untrustworthy than feeling in determining humanity. By sight, color became an appropriate index for saying who was a man, and the evil of racial discrimination was given foundation. Nor can touch provide the test; a being confined by sickness, "out of touch" with others, does not thereby seem to lose his humanity. To the extent

\footnotetext{
174 This line of thought was advanced by some participants at the International Conference on Abortion sponsored by the Harvard Divinity School in Washington, D. C., Sept. 8-10, 1967.

175 Frank D. Allan, Essentials of Human Embryology 165 (1960).

170 Frederick J. Gottleib, Developmental Genetics 28 (1966).

177 Allan, op. cit. supra note 175 , at 165.
} 
that touch still has appeal as a criterion, it appears to be a survival of the old English idea of "quickening"- a possible mistranslation of the Latin animatus used in the canon law. ${ }^{178}$ To that extent touch as a criterion seems to be dependent on the Aristotelian notion of ensoulment, and to fall when this notion is discarded.

Finally, a distinction is sought in social visibility. The fetus is not socially perceived as human. It cannot communicate with others. Thus, both subjectively and objectively, it is not a member of society. As moral rules are rules for the behavior of members of society to each other, they cannot be made for behavior towards what is not yet a member. Excluded from the society of men, the fetus is excluded from the humanity of men. ${ }^{179}$

By force of the argument from the consequences, this distinction is to be rejected. It is more subtle than that founded on an appeal to physical sensation, but it is equally dangerous in its implications. If humanity depends on social recognition, individuals or whole groups may be dehumanized by being denied any status in their society. Such a fate is fictionally portrayed in 1984 and has actually been the lot of many men in many societies. In the Roman empire, for example, condemnation to slavery meant the practical denial of most human rights; in the Chinese Communist world, landlords have been classified as enemies of the people and so treated as nonpersons by the state. Humanity does not depend on social recognition, though often the failure of society to recognize the prisoner, the alien, the heterodox as human has led to the destruction of human beings. Humanity is an attribute which

178 The first reference to abortion in English criminal law occurs in Bracton. He transposed the canon Sicut ex to England by saying that aborting a woman by blow or poison is homicide if the embryo "were formed and especially if it were ensouled" (animatum), Henry de Bracton, De legibus et consuetudinibus Anglaz 3.2.4 (London, 1640). This language was repeated early in the seventeenth century by Coke in a passage which begins, "If a woman be quick with child ... this is a great misprision and so murder," Edward Coke, The Third Part of the Institutes op the Laws of England sec. 50 (London, 1797). Later in the seventeenth century "quick" is clearly identified with "developed pregnancy." Hale says, "If a woman be quick or great with child . . it is not murder or manslaughter by the law of England, because it is not yet in rerum matura, tho it be a great crime ...", Matthew Hale, The History of the Pleas of the Grown (American ed., Philadelphia, 1847). The statutory law, 43 Geo. III c. 58, which became effective in 1803, made it a felony punishable by death to administer poison "to cause and procure the miscarriage of any woman then quick with child," and a felony punishable by fine, imprisonment, pillory, whipping or transportation to attempt by drug or instrument to procure the miscarriage of any woman "not being or not being proved to be quick with child." In Rex v. Phillips in 1812, the doctors disagreed as to when a fetus could be said to be quick, and the court ruled that it was quick when the mother felt the fetus move. See William O. Russeli, 1 A Treatise on Crimes and Misdemeanors 797 (London, 1819). In later nineteenth century America, "quick" was defined in the same way, despite doubts as to the medical significance of the term and a tendency to interpret abortion statutes as applicable to any stage of the pregnancy. See JozL P. Bishop, Commentaries on the Law op Statutory Crimes sec. 746 (2nd ed., Boston, 1883).

178 Another line of thought advanced at the Conference mentioned in note 174. 
anyone conceived by a man and a woman has. Recognition of this condition by society follows a real event in the objective order, however imperfect and halting the recognition. Any attempt to limit humanity to exclude some group runs the risk of furnishing authority and precedent for excluding other groups in the name of the consciousness or perception of the controlling group in the society.

The rejection of the attempted distinctions may be buttressed by the following considerations: Moral judgments often rest on distinctions, but if the distinctions are not to appear arbitrary fiat, they should relate to some real difference in probabilities. There is a kind of continuity in all life, but the earlier stages of the elements of human life possess tiny probabilities of development. Consider, for example, the spermatozoa in any normal ejaculate: there are about 200,000,000 in any single ejaculate, of which one has a chance of developing into a zygote. ${ }^{180}$ Consider the oocytes which may become ova: there are 100,000 to $1,000,000$ oocytes in a female infant, of which a maximum of 390 are ovulated. ${ }^{181}$ But once spermatozoon and ovum meet and the conceptus is formed, such studies as have been made show that roughly in only $20 \%$ of the cases will spontaneous abortion occur. ${ }^{182}$ In other words, the chances are about 4 out of 5 that this new being will develop. At this stage in the life of the being there is a sharp shift in probabilities, an immense jump in potentialities. To make a distinction between the rights of spermatozoa and the rights of the fertilized ovum is to respond to an enormous shift in possibilities. As life itself is a matter of probabilities, as most moral reasoning is an estimate of probabilities, so it seems in accord with the structure of reality and the nature of moral thought to found a moral judgment on the change in probabilities here. At the point where the conceived being has a better than even chance of developing, he is a man.

This line of thought may be supported by the further consideration that at conception the new being receives the genetic code. ${ }^{183}$ It is this genetic information which determines his characteristics, which is the biological carrier of the possibility of human wisdom. A being with the human genetic code is homo sapiens in potency; and his potential capacity to reason makes him share in the universal characteristic of man. Man is always in the process of learning. No one is full human. If the fetus is potentially human, so is the adult. Capacity to be human alone is common.

This review of current controversy over the humanity of the fetus empha-

180 J. S. Baxter, Frazer's Manual of Embryology 5 (1963).

181 Gregory Pincus, The Control of Fertility 197 (1965).

182 Idem. Apparently there is some small variation by region.

183 GotTlers, op. cit. supra note 176, at 17. 
sizes what a fundamental question the theologians resolved in asserting the inviolability of the fetus. To regard the fetus as possessed of equal rights with other humans was not, however, to decide every case where abortion might be employed. It did decide the case where the argument was that the fetus should be aborted for its own good. To say a being was human was to say it had a destiny to decide for itself which could not be taken from it by another man's decision. But human beings with equal rights often come in conflict with each other, and some decision must be made as whose claims are to prevail. Cases of conflict involving the fetus are different only in two respects: the total inability of the fetus to speak for itself and the fact that the right of the fetus regularly at stake is the right to life itself.

The approach taken by the theologians to these conflicts was articulated in terms of "direct" and "indirect." Again, to look at what they were doing from outside their categories, they may be said to have been drawing lines or "balancing values." "Direct" and "indirect" are spatial metaphors; "linedrawing" is another. "To weigh" or "to balance" values is a metaphor of a more complicated mathematical sort hinting at the process which goes on in moral judgments. All the metaphors suggest that, in the moral judgments made, comparisons were necessary, that no value completely controlled. The principle of double effect was no doctrines fallen from heaven, but a method of analysis appropriate where two relative values were being compared. In Catholic moral theology, as it developed, life even of the innocent was not taken as an absolute. Judgments on acts affecting life issued from a process of weighing. In the weighing, the fetus was always given a value greater than zero, always a value separate and independent from its parents. This valuation was crucial and fundamental in all Christian thought on the subject and marked it off from any approach which considered that only the parents' interests needed to be considered.

Even with the fetus weighed as human, one interest could be weighed as equal or superior: that of the mother in her own life. The casuists between 1450 and 1895 were willing to weigh this interest as superior. Since 1895, that interest was given decisive weight only in the two special cases of the cancerous uterus and the ectopic pregnancy. In both of these cases the fetus itself had little chance of survival even if the abortion were not performed. As the balance was once struck in favor of the mother whenever her life was endangered, it could be so struck again. The balance reached between 1895 and 1930 attempted prudentially and pastorally to forestall a multitude of exceptions for interests less than life.

The perception of the humanity of the fetus and the weighing of fetal rights against other human rights constituted the work of the moral analysts. 
But what spirit animated their abstract judgments? For the Christian community it was the injunction of Scripture to love your neighbor as yourself. The fetus as human was a neighbor; his life had parity with one's own. The commandment gave life to what otherwise would have been only rational calculation.

The commandment could be put in humanistic as well as theological terms: Do not injure your fellow man without reason. In these terms, once the humanity of the fetus is perceived, abortion is never right except in selfdefense. When life must be taken to save life, reason alone cannot say that a mother must prefer a child's life to her own. With this exception, now of great rarity, abortion violates the rational humanist tenet of the equality of human lives.

- For Christians the commandment to love received had a special imprint in that the exemplar proposed of love was the love of the Lord for his disciples. In the light given by this example, self-sacrifice carried to the point of death seemed in the extreme situations not without meaning. In the less extreme cases, preference for one's own interests to the life of another seemed to express cruelty or selfishness irreconcilable with the demands of love. 